\title{
The Decision to File Federal Criminal Charges: A Quantitative Study of Prosecutorial Discretion
}

\author{
Richard S. Frase $\dagger$
}

A recurring problem in criminal justice administration is the exercise of discretion-in particular, the decision whether or not to invoke formal penalties or procedures. All discretion is subject to abuse, but the "discretion to be lenient" poses especially difficult problems because it tends to be less visible, and because its "victims"-complaining parties, the public at large, and other defendants who did not receive leniency-have traditionally had few if any means to contest these decisions. ${ }^{1}$ The most visible forms of leniency in the later stages of the criminal justice process have recently come under severe attack. Thus, one of the major objections to traditional plea bargaining practices has been that they seem to result in a general (but inconsistent) "watering down" of charges." Similarly, recent proposals for mandatory sentencing reflect, in

$\dagger$ Associate Professor of Law, University of Minnesota. This study was supported by the National Institute of Law Enforcement and Criminal Justice, Law Enforcement Assistance Administration, U.S. Department of Justice, Grant No. 75-NI-99-0114. The opinions and conclusions expressed in this paper are those of the author, however, and do not necessarily reflect the views of the funding agency.

The study is part of a larger project, which examined not only the decision to prosecute but also pretrial release decisions, methods of disposition in prosecuted cases, and sentencing patterns. These findings are reported in the final report to the Law Enforcement Assistance Administration, pursuant to the grant mentioned above, entitled "Processing of Federal Criminal Matters in the Northern District of Illinois" (Feb. 1, 1977). Ms. Giannina Rikoski, a research associate at the Center for Studies in Criminal Justice, The University of Chicago Law School, played a major role in formulating the overall research design of the project and supervised data collection efforts. This larger project was originally requested and sponsored by the United States Bureau of Prisons, as part of its research program for the Metropolitan Correctional Center, which opened in Chicago in September, 1975. Special thanks are due to Mr. Norman Carlson, Director of the Bureau of Prisons, and to the staff of the Chicago Metropolitan Correctional Center, for their encouragement and support. The author also wishes to thank the staff of the United States Attorney's Office for the Northern District of Illinois for its cooperation in conducting the study. Helpful comments on an earlier draft of this paper were received from Professor Barry Feld of the University of Minnesota Law School. Professor Franklin Zimring, Director of the Center for Studies in Criminal Justice, The University of Chicago Law School, provided essential support, advice, and encouragement throughout the project.

See generally K. Davis, Discretionary Justice 170-72 (1969).

2 See, e.g., U.S. National Advisory Comm'N ON CRiminal Justice Standards and Goals, CouRts Standard 3.1, at 46 (1973) (proposal to abolish all plea negotiation by 1978). 
part, a concern that the criminal justice system is treating some offenders too leniently. ${ }^{3}$

It has long been recognized, however, that police and prosecutors exercise even broader discretion in the arrest and screening stages that precede the filing of formal charges." These decisions are made at perhaps the least visible stages of the criminal justice process, and they are subject to few legal controls. ${ }^{5}$ Yet if these decisions are completely unregulated, the value of closely controlling the later, more visible stages of procedure is slight. Police and prosecutors can evade even the strictest plea bargaining and sentencing controls by simply not arresting or charging certain offenders, or not charging certain offenses. ${ }^{6}$ Thus, the existing, broad discretion of police and prosecutors raises important policy issues: Who should be arrested or prosecuted, and on what charges? When is it appropriate to treat "similar" offenders differently? Are improper motives playing any part in the selection process? What kinds of procedures can be devised to regulate or limit these decisions, so that desirable substantive policy can be enforced??

${ }^{3}$ See, e.g., ILl. Rev. Stat. ch. 38, \& 1005-5-3(c)(2) (Supp. 1979) (requiring the sentencing judge to impose a prison term, rather than probation, upon conviction of certain offenses).

- See President's Comm'n on Law Enforcement and Administration of Justice, The Challenge of Crime in a Free Society 10-11, 133 (1967).

- See text and notes at notes 145-154 infra.

- For a discussion of the effect of mandatory minimum sentences on prosecutorial charging decisions, see Zimring, Eigen \& O'Malley, Punishing Homicide in Philadelphia: Perspectives on the Death Penalty, 43 U. CHI. L. REv. 227 (1976).

2 The simplest answer to these problems would be to abolish all discretion and institute a requirement of full enforcement. But the necessity and legitimacy of selective arrest and prosecution can be defended on a number of grounds. First, some of the offenders accused by victims or the police are innocent; they should be screened out of the system as soon as possible, to minimize the hardships of false accusation. Other offenders, although probably guilty, are unconvictable due to problems of proof, illegal searches, and the like. Since litigation is expensive, it makes sense to screen out these weak cases as soon as it becomes apparent that further investigation will not yield sufficient evidence to obtain a conviction. Second, even if defendants are convictable, they may not be persons whom the legislature intended to punish. Some laws (for example, gambling) are intentionally overbroad, so as to confront the professional criminal with "a statutory facade that is wholly devoid of loopholes." LaFave, The Prosecutor's Discretion in the United States, 18 Aм. J. Comp. L. 532, 533 (1970) (quoting 2 A.B.A. Comm'n on Organized Crime, Organized Crime and Law EnFORCEMENT 75 (1952)). Other examples of legislative "overcriminalization" involve legislative attempts to uphold "morals," with no expectation (in modern times, at least) that the laws will be enforced-for example, laws againt fornication and adultery. Id. Even laws that are meant to be generally enforced may properly not be invoked on occasion. Since the legislature cannot foresee all factual situations and mitigating circumstances that may arise, selective enforcement is necessary in order to individualize justice. Id. at 534. Indeed, there may be cases in which nonprosecution, or some alternative to prosecution such as restitution, 
The purpose of the present study is to contribute to a better understanding of the nature of these invisible discretionary decisions and of the need for and feasibility of various internal and external controls such as administrative rulemaking and judicial review. It focuses on prosecutorial rather than police discretion, largely because prosecutors keep more complete records. The inquiry is further narrowed to the decision whether or not to prosecute; the more complex (and usually undocumented) decision concerning which charges to file remains an important area for further research.

There have been a number of recent studies of the reasons for nonprosecution in federal and state courts, ${ }^{8}$ but most have not gone beyond an impressionistic presentation of the different rationales and concepts. For example, although we know that all prosecutors eliminate cases for insufficient evidence, ${ }^{8}$ we have no quantitative measure of the relative importance of this factor in relation to (or in combination with) other factors weighing for or against prosecution. Indeed, we have very little data on the rates, let alone the reasons, for nonprosecution. ${ }^{10}$

The present study examines the exercise of discretion by federal prosecutors. These decisions generally occur prior to the point at which an arrest is made, ${ }^{11}$ and are fully documented by the as-

may be preferable to formal prosecution. Finally, selective enforcement may simply be an economic necessity. Given insufficient resources to arrest and prosecute all offenders who "ought" to be prosecuted, it makes sense to focus on the more serious cases.

s E.g., F. Miller, Prosecution: The Decision to Charge a Suspect with a Crime (1969); Rabin, Agency Criminal Referrals in the Federal System: An Empirical Study of Prosecutorial Discretion, 24 Stan. L. Rev. 1036, 1044-72 (1972). See generally W. Tesurk, Prosecutorial Discretion: The Decision to Charge (1975).

9 F. Miller, supra note 8, at 9-149.

10 Perhaps the best quantitative study of such reasons was an analysis of the disposition of felony arrests in Los Angeles County, showing not only the rates of prosecution, by offense, but also the reasons cited for nonprosecution of two offenses: burglary and possession of dangerous drugs. P. Greenwood, S. Wildhorn, E. Poggio, M. Strumwasser \& P. DE Leon, Prosecution of Adult Felony Defendants in Los Angeles County: A Policy PerSPECTIVE (1973). Reasons for nonprosecution of other offenses were not reported, however, and a further limitation of the study is that it fails to address the arrest decision itself.

Other recent studies of the disposition of arrested defendants include J. EISENSTEIN \& H. Jacob, Felony Justice: An Organizational Analysis of Criminal Courts (1977) (covering Baltimore, Chicago, and Detroit); National. Institute of Law Enforcement and Criminal Justice, U.S. Dep't of Justice, Highlights of Interim Findings and Implications (1977) (Washington, D.C. Superior Court); Vera Institute of Justice, Felony Arrests: Their Prosecution and Disposition in New York City's Courts (1977). See also McIntyre \& Lippmann, Prosecutors and Early Disposition of Felony Cases, 56 A.B.A. J. 1154 (1970) (showing estimated screening rates by police, prosecutors, and courts in six cities).

${ }^{11}$ See text at note 24 infra. Some federal law enforcement agencies engage in consider- 
sistant prosecutors involved. Although the nature of federal crime is quite different from the typical state or local offense, ${ }^{12}$ previous studies of federal prosecutors ${ }^{13}$ suggest that many of the basic reasons for prosecution and nonprosecution in federal and state cases are similar.

By examining both the characteristics of cases prosecuted and declined, and the reasons asserted for nonprosecution, this study will identify and measure the factors that govern prosecution decisions, and will assess the extent to which these operating principles are consistently and efficiently applied. The policy implications of these findings will then be considered. Finally, a series of appendices will set forth in more detail the methodology of the study, and refine the basic empirical data presented in the text.

\section{Prosecutorial Discretion and the Federal Criminal JUSTICE SYSTEM}

Prosecution of federal criminal cases in each of the ninety-four judicial districts is the responsibility of the United States Attorney, who is appointed by the President for a four-year term. ${ }^{14}$ Thus, unlike most of his state and local counterparts, the federal prosecutor is not an elected official, and is not subject to popular political pressures, although he may be removed by the President. ${ }^{15}$ U.S. Attorneys are also subject to overall supervision by the

able screening of criminal matters prior to referral to U.S. Attorneys, see Rabin, supra note 8, at 1039-40, 1052-53; see also note 17 infra, not referring matters that they know will be subsequently declined, Rabin, supra note 8 , at 1053 . This study did not examine the exercise of such pre-referral discretion, but still probably sheds some light on the nature and extent of pre-referral screening. See text and notes at notes 43,45 infra; note 38 infra.

12 There is, however, a large degree of overlap between state and federal criminal jurisdiction. See text at note 18 infra.

15 E.g., J. EIsEnstein, Counsel for the United States (1978); Baker, To Indict or Not to Indict: Prosecutorial Discretion in Sherman Act Enforcement, 63 CoRnell L. Rev. 405 (1978); Beck, The Administrative Law of Criminal Prosecution: The Development of Prosecutorial Policy, 27 AM. U.L. REv. 310 (1978); Kaplan, The Prosecutorial Discretion-A Comment, 60 Nw. U.L. Rev. 174 (1965); Rabin, supra note 8; Ruff, Federal Prosecution of Local Corruption: A Case Study in the Making of Law Enforcement Policy, 65 Geo. L.J. 1171 (1977); Schwartz, Federal Criminal Jurisdiction and Prosecutors' Discretion, 13 Law \& Contemp. Prob. 64 (1948); Note, The Petite Policy: An Example of Enlightened Prosecutorial Discretion, 66 Gro. L.J. 1137 (1978) [hereinafter cited as Note, The Petite Policy]; Note, Prosecution Under the Hobbs Act and the Expansion of Federal Criminal Jurisdiction, 66 J. Crim. L. \& Criminology 306 (1975).

1428 U.S.C. § 541(a) (1976).

${ }^{15} I d$. § $541(\mathrm{c})$. This power is rarely used except when a new President chooses to replace all U.S. Attorneys. See J. Eisenstern, supra note 13, at 97-98, 111. 
Department of Justice in Washington, ${ }^{16}$ and certain kinds of cases are screened by Department of Justice attorneys. ${ }^{17}$ In most cases, however, the U.S. Attorney has complete control over which charges, if any, will be filed in his district.

Federal criminal laws frequently overlap with state statutes, permitting the federal prosecutor additional flexibility in the selection of cases. For example, most federal theft, fraud, and narcotics violations are also violations of state law. Since the police power is a state function, ${ }^{18}$ the federal prosecutor may believe that primary responsibility for the prosecution of such offenses lies with state authorities. Thus, U.S. Attorneys often decline low-priority cases in favor of state prosecution, whereas state deferral of such cases to federal prosecution is generally deemed less appropriate. ${ }^{19} \mathrm{An}$ other large category of federal crimes involves violations of administrative or regulatory schemes, for which a wide variety of civil or administrative remedies is available as alternatives to prosecu-

10 The Attorney General "shall supervise all litigation to which the United States, an agency, or officer thereof is a party, and shall direct all United States Attorneys . . . in the discharge of their respective duties." 28 U.S.C. $\$ 519$ (1976). Section 542 of Title 28 gives the Attorney General power to appoint and remove all Assistant United States Attorneys, and section 547(5) requires each United States Attorney to "make such reports as the Attorney General may direct." Pursuant to this authority, the Department requires all U.S. Attorneys to submit statistics on the filing and disposition of all civil and criminal cases, as well as the nature and disposition of all civil and criminal investigations in which any attorney spends at least one hour of time. ExEcutrive OFFICE FOR U.S. ATtORNEYs, U.S. DEP'T OF Justice, United States Attorney's Docket and Reporting System (1973) [hereinafter cited as U.S. AtTorney's Docket and Reporting System]. The Department has also issued a U.S. Attorney's Manual and periodic directives and guidelines for the handling of particular kinds of cases, but many U.S. Attorneys ignore these instructions. See J. EISENSTEIN, supra note 13, at 66-67; Note, The Petite Policy, supra note 13, at 1143-44. See also Materials Relating to Prosecutorial Discretion, 24 CRIM. L. REP. (BNA) 3001 (Nov. 22, 1978) (reprint of two Department of Justice memoranda containing general guidelines for prosecution and charging decisions, plea bargaining, and handling of defendants who "cooperate"; these policy statements are expressly nonbinding on any federal prosecutor).

${ }^{17}$ For example, all income tax prosecutions require Department of Justice approval, and the IRS refers its cases directly to the Department rather than to local U.S. Attorneys. See Rabin, supra note 8, at 1039-40. During the period covered by our study, the Department did not approve about $10 \%$ of the referrals received from the IRS. See [1974] U.S. Dep't of Justice, Att'y Gen. Ann. Rep. 146.

${ }^{18}$ For a discussion of the historical development of federal criminal jurisdiction, see Schwartz, supra note 13, at 64-66.

10 State prosecutors may be able to transfer responsibility for some cases to other state prosecutors. For example, attorneys general in most states enjoy statutory or common-law authority to prosecute some or all criminal offenses, even though local prosecutors also have jurisdiction. See National Ass'n of Attorneys General, Powers, Duties and Operations of State Attorneys General 104-07 (1977). 
tion. ${ }^{20}$ Finally, since much federal crime involves interstate movement $^{21}$ and prosecution is normally appropriate in any district affected, ${ }^{22}$ a number of federal offenses are reported to more than one U.S. Attorney, even though ultimately only one office will prosecute the case.

The extent to which the U.S. Attorneys take advantage of this relative freedom to decline prosecution is indicated in Table 1: less than one-fourth of the complaints received by the ninety-four U.S. Attorneys appear to result in the filing of formal charges. As shown in Table 2, this estimated rate of prosecution varies considerably by offense. These figures must be viewed as rough estimates, since the cases filed in a given year are not necessarily the same complaints received that year, and, as indicated in the notes to Table 1 , the published figures on complaints and cases filed tend to overstate the number of "new" charges. Nevertheless, it seems likely that the overall federal prosecution rate for the nation as a whole is no more than $25 \%$, and probably no less than $20 \%$. These figures are considerably lower than the prosecution rates in state systems for which published data are available. ${ }^{23}$

It should also be noted that of the 120,000 matters that go unprosecuted each year, the vast majority do not involve any arrest or other formal apprehension of the suspect. Published court statistics suggest that only about 23,000 suspects are arrested but not prosecuted each year; this total probably represents about 17,000 matters. ${ }^{24}$ Thus, the prosecutorial discretion of the U.S. Attorney operates at a stage of procedure that, in state criminal justice systems, is much more likely to be controlled by the police. Analysis of these prearrest complaints and the reasons given for not filing formal charges therefore provides a unique opportunity to examine

${ }^{20}$ See Rabin, supra note 8, at 1058-61.

${ }^{21}$ E.g., 18 U.S.C. $\$ 2312$ (1976) (interstate transport of stolen motor vehicle or aircraft).

22 See id. \$ 3237.

${ }^{23}$ See, e.g., P. Greenwood, S. Wildhorn, E. Poggio, M. Strumwasser \& P. de Leon, supra note 10 (overall felony prosecution rate varying from $46 \%$ to $55 \%$ ).

24 United States magistrates processed about 37,000 initial appearances of unindicted defendants per year, in 1976 through 1978. See [1976] Admin. OfFICE of THE U.S. Courts ANN. Rep. Table M-3, at 423; [1977] id. at 492; [1978] id. at 514. About 14,000 of these defendants were subsequently prosecuted. See Admin. OfFICE of THE U.S. Courts, FourTh Report on the Implementation of Titre I of the SpEedy Trial ACT of 1974, at A-2 (1979) (total pre-indictment arrests in the two-and-one-half-year period ending December 31, 1978, divided by two and one-half). The difference, 23,000 defendants, includes many multi-defendant cases; based on the ratio of 1.4 defendants per case, reflected in published figures for prosecuted defendants, see [1976] Admin. Office of the U.S. Courts AnN. Rep. Table M-3, at 423; [1977] id. at 492; [1978] id. at 514, 23,000 defendants would represent about 17,000 matters. 
TABLE 1

Prosecution Rates for U.S. ATtorneys

\begin{tabular}{lccc}
\hline \hline Fiscal Year & $\begin{array}{c}\text { New Criminal } \\
\text { Matters Received }\end{array}$ & $\begin{array}{c}\text { New Criminal } \\
\text { Cases Filed b }\end{array}$ & $\begin{array}{c}\text { Estimated Percentage } \\
\text { of Cases Prosecuted c }\end{array}$ \\
\hline 1974 & 160,670 & 35,440 & 22.1 \\
1975 & 163,301 & 38,227 & 23.4 \\
1976 & 161,968 & 36,349 & 22.4 \\
1977 & 148,731 & 30,565 & 20.6 \\
1978 & 144,074 & 28,745 & 20.0 \\
& & & 21.7 \\
5-year & & 33,865 & \\
\hline
\end{tabular}

Source: U.S. Dep'T OF Justice, United States AtToRneys' OfFice Statistical REPORT Table 7 (1974); id. (1975); id. (1976); id. (1977); id. (1978).

a The published figures for "matters received" include some double counting: appeals and superseding indictments are counted as additional "matters," and transfers under Rules 20 and 40 of the Federal Rules of Criminal Procedure are counted as one "matter" in both districts affected. To arrive at estimates of "new matters" received in each year, these cases have been subtracted, using figures obtained from the above source and from [1974] ADMIN. OFFICE OF U.S. Courts ANN. REP. Table M-3, at 548; [1975] id. at 499; [1976] id. at 423; [1977] $i d$. at 492 ; [1978] id. at 514 .

b The published figures for "cases filed" include all of the above forms of double counting except Rule 40 transfers. Again, these cases have been subtracted to arrive at estimates of "new cases" filed for each year.

c The percentage is the ratio of cases filed to matters received. Because the cases filed in any given year are not always received as matters in that year, the figures for individual years are less reliable than the five-year average. If the various forms of double counting referred to above were not subtracted, the prosecution rates would appear somewhat higher - for example, $25.1 \%$ for the five-year average.

the exercise of discretion at the earliest stages of the criminal justice process.

The present study was conducted in the Northern Distict of Illinois, which includes metropolitan Chicago and most of the northern section of the state. ${ }^{25}$ Several factors make this district particularly suitable for such a study. First, the district contains a

${ }^{25}$ For the specific counties included in the district, see 28 U.S.C. $\$ 93(a)$ (1976). During the period covered by our study, the district had thirteen federal judges, three full-time magistrates, and one part-time magistrate. There were approximately $\mathbf{7 0}$ lawyers in the U.S. Attorney's office, but only 10 to 15 were actively involved in screening decisions. 
TABLE 2

Prosecution Rates for U.S. AtTorneys by OFFense 1974-1978

Offense
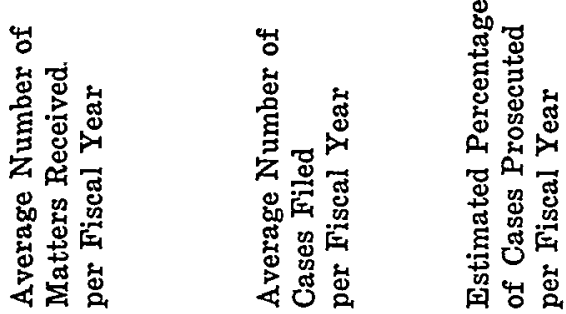

Controlled substances

\begin{tabular}{rrr}
9,911 & 6,619 & 66.8 \\
11,380 & 935 & 8.2 \\
5,829 & 136 & 2.3 \\
9,754 & 2,736 & 28.1 \\
5,770 & 797 & 13.8 \\
5,477 & 1,667 & 30.4 \\
9,620 & 1,351 & 14.0 \\
8,484 & 1,282 & 15.1 \\
6,506 & 3,172 & 48.8 \\
4,202 & 2,926 & 69.6 \\
88,498 & 19,962 & 22.6 \\
\hline 165,432 & 41,583 & 25.1 \\
\hline
\end{tabular}

SoURCe: U.S. Dep'T of JUSTICe, UNITed States AtTorneys' OfFice Statistical REPORT at 3 \& Table 3 (1974); id. (1975); id. (1976); id. (1977); id. (1978).

NOTE: The figures for "matters received" include appeals, superseding charges, and double counting of Rule 20 transfers and Rule 40 removals. See Table 1, note a. The figures for "cases filed" include appeals, superseding charges, and double counting of Rule 20 transfers. See Table 1, note b. If it were practicable to exclude these in the analysis by offense, the estimated prosecution rates shown here would probably be slightly lower. See Table 1 , note c.

large and varied caseload, ${ }^{26}$ which makes it possible to study prosecution decisions within a fairly narrow time span-so as to minimize the impact of shifting crime rates or changes in applicable law or personnel-and still have, a large enough sample to permit

${ }^{26}$ In fiscal year 1974, there were 796 original criminal proceedings filed in the Northern District, and 53 other cases were received by transfer from other districts. [1974] ADMIN. Office of THE U.S. CouRTS, ANN. REP. Table D-1, at 459 . Nine of the other 93 federal judicial districts had a higher total number of criminal cases filed in that year. Id. 
statistical analysis. The Northern District also appears to have a prosecution rate that is even lower than the national average. ${ }^{27}$ Such selectivity calls for closer examination, and it also seems likely to provide a rich source of insights into the exercise of discretion.

Perhaps the most important reason for studying prosecution decisions in the Northern District, however, relates to the nature of the pretrial screening procedures used there. When a criminal matter is referred to the U.S. Attorney for the Northern District, an entry is made in a daily log book and an initial screening decision is made by the Chief of the Criminal Division. About $50 \%$ of all matters are identified as "immediate declinations"28 at this stage, but regardless of the preliminary screening decision, each matter is assigned to an Assistant U.S. Attorney, who examines the offense in more detail and recommends prosecution or declination. $^{2 \theta}$ For all recommended declinations, the reasons justifying nonprosecution are written up by the Assistant in the form of a file memorandum. The memorandum is then attached to the case file and circulated for review by the Chief of the Criminal Division and the First Assistant U.S. Attorney. The research value of this system is twofold: it permits quantitative analysis of the reasons for nonprosecution, and it provides a case study of an administrative procedure designed to maintain consistent enforcement of office prosecution policies.

27 In fiscal years 1971 through 1975, the Northern District received an average of 5,420 criminal matters per year. An average of 1,012 criminal cases were filed each year during this period, which yields an estimated gross prosecution rate of $19 \%$; for all 94 districts, the rate was 27\%. U.S. Dep'T of Justice, United States Attorneys' Office Statistical RePORT, 'Table 7 (1971) [hereinafter cited as U.S. Attorneys' Office Statistical RePoRT]; id. (1972); id. (1973); id. (1974); id. (1975). As indicated in the notes to Table 1, these figures include appeals, superseding charges, and other forms of double counting. If all instances of double counting could be removed, as was done in Table 1 , the estimated prosecution rate for the Northern District would probably be around 16\%; for all 94 districts it was $24 \%$.

${ }_{28}$ These unprosecuted cases are referred to as "miscellaneous" matters by Northern District staff, but I will use the term "immediate declinations" throughout this article, so as to contrast these matters with declinations entered at later stages of office screening. See Appendix $\mathrm{C}$ infra.

It is unknown whether or not this preliminary-screening procedure is employed in most federal districts. The U.S. ATtorneY's Docket AND REPORTING System, supra note 16, permits U.S. Attorneys to submit only a monthly summary of those declinations in which prosecution is immediately declined, but this statistical directive does not require U.S. Attorneys to adopt any particular screening procedure.

29 Several "immediate declinations" in our study were subsequently reconsidered, and three were actually prosecuted, which indicates that the preliminary screening decision is not final. 


\section{The Research Methodology}

The basic research methodology employed in this study involved use of a random sample of 800 "matters" received by the U.S. Attorney for the Northern District of Illinois from October 1, 1973, through March 31, 1974. A "matter" was defined as any complaint logged in by the Criminal Division during this period that had not previously been received by the office in any form. ${ }^{30}$ This cohort of new matters was then followed to disposition, and all available information on all suspects in each matter was coded from files in the U.S. Attorney's office, court records, and U.S. Marshal's office records. ${ }^{31}$ This longitudinal approach permits the comparison of characteristics of defendants whose prosecutions

so We sampled $300(28 \%)$ of the 1,086 matters that were declined immediately during the six-month study period, and 500 (46\%) of the 1,087 other matters received. After elimination of matters that had previously been received, our total sample consisted of 758 matters, containing 1,071 suspects. We sampled a higher proportion of matters not declined immediately, in order to obtain enough prosecuted cases to permit detailed analysis. The figures on total matters and declinations reported in this article have been adjusted to compensate for the different sampling fractions used.

${ }^{31}$ We were given free access to the U.S. Attorney's files of all declined cases in our sample, and these files proved a rich source of data. In addition to the declination memoranda described in the text, the files revealed many details of the offense: use of force, nature of the victim, dollar amount of loss, nature and amount of drugs, number of guns, and the like. They sometimes contained information on the age and prior record of defendants, although the large proportion of missing data prevents any thorough analysis of these variables.

We did not have access, however, to the U.S. Attorney's files on the prosecuted cases in our sample, so it was necessary to obtain the details of offenses and offenders from U.S. magistrate and district court files-for example, statements of prior record made at bail hearings and offense details stated in complaints and indictments. We also had access to the records of the U.S. Marshal for the Northern District, which contained specific information such as age, arrest date, and periods of pretrial detention. With the exception of prior record, we were able to obtain sufficient information from such other sources to permit comparisons of matters prosecuted and declined.

Given the different data sources used, it might be suggested that declined and prosecuted matters are not really comparable, since data on the latter may reflect investigations completed after the decision to prosecute was made. To some extent, of course, this problem would arise even if we had complete access to the prosecutor's files. In any case, there are several reasons to believe that most charges are known at the time of initial referral, and that, at least for cases not declined immediately, the extent of investigation is comparable to that accorded prosecuted cases. A comparison of indictment charges with those shown in earlier logbook and magistrate records reveals that relatively few charges are added, and those that are usually reflect different legal theories, such as conspiracy, rather than discovery of new crimes. Our study also revealed that cases that are declined, but not immediately, actually remain open in the office much longer than prosecuted ones; this finding suggests that the former do not necessarily involve premature termination of investigation.

The study thus proceeds on the assumption that the data on declined and prosecuted offenses are "comparable." In light of the added offenses mentioned above, however, any comparisons of offenses are based on logbook charges only. 
were declined or effected contemporaneously, and who were thus presumably subject to equivalent screening standards. The collection of offense and offender characteristics for matters declined and prosecuted also permits inferences to be made as to additional factors, not reflected in the reasons given for declination, that weigh in favor of prosecution or declination.

Declination memoranda prepared by Assistant U.S. Attorneys all followed the same format, but the exact phrasing of the reasons for declination showed considerable variation. In order to permit computer tabulation of these reasons for the over 500 defendants in our sample whose prosecutions were declined, it was necessary to establish specific categories of reasons. Three major reasons-hereafter referred to as "categories"-for declination were recognized in this study. First were problems of "convictability"-Cases with an insufficient legal or factual basis. Second was the availability of criminal or civil alternatives to prosecution, such as parole revocation. And third were "policy" reasons weighing against prosecution-for example, the value of the defendant's services as an informer or prosecution witness. The specific reason groups, within each of these major categories, are illustrated in Table 6. Additional theoretical and methodological aspects of this analytical framework are discussed in Appendix A.

\section{Characteristics of Matters Declined and Prosecuted}

The overall results of the sample confirm the earlier estimates of prosecution rates in the Northern District, based on published statistics. ${ }^{32}$ Sixteen percent of the matters in our sample, or $20 \%$ of defendants, had been prosecuted as of February 1976, which was almost two years after the most recent matter was received by the Criminal Division. Four percent of the matters were still pending, and if all of these are eventually prosecuted, the sample prosecution rate will rise to $20 \%$ ( $23 \%$ of defendants). It seems highly unlikely, however, that very many matters that have remained open more than two years would be prosecuted. ${ }^{33}$ If one excludes pending matters and certain other cases not subject to prosecutorial discretion in the Northern District, ${ }^{34}$ the overall

32 See note 27 supra.

${ }^{33}$ Most of the prosecuted defendants in our sample were indicted within a few months of the date of referral to the U.S. Attorney, and less than $5 \%$ were indicted more than one year after the date of referral.

${ }^{34}$ Sixty sample suspects (in 59 cases), charged with unlawful flight to avoid state prosecution ("UFAP"), see 18 U.S.C. $\$ 1073$ (1976), were excluded from the analysis. The pur- 
prosecution rates are: $17 \%$ of matters, and $21 \%$ of defendants.

\section{A. Offenses Most Frequently Declined and Offenses Most Frequently Prosecuted}

As shown in Table 3, the decision to prosecute appears to be closely related to the offense involved. ${ }^{36}$ For example, cases involving importation of marijuana or other drugs were rarely prosecuted, whereas cases involving sale or distribution of drugs were prosecuted more frequently than the average. This distinction is not as incongruous as it seems; "importing" cases typically involved attempts to mail small amounts of the drug into the country, whereas the "sale" cases involved much larger amounts, with commercial or conspiracy aspects. A similar distinction exists between interstate-transport-of-stolen-motor-vehicle ("Dyer Act") cases, with and without a conspiracy charge. The latter typically involve youthful offenders caught "joyriding," whereas the conspiracy charges involved organized rings of professional car thieves. Other cases that were almost never prosecuted include theft of government property, theft from interstate shipment, miscellaneous frauds, civil rights cases, ${ }^{37}$ and simple assaults. Offenses with

pose of this statute is to give the FBI jurisdiction to assist state authorities in rounding up fugitives who cross state lines. No UFAP prosecutions have been brought in the Northern District for many years. Moreover, since UFAP prosecution must be brought in the district where the state offense occurred, most of the UFAPs in our sample could not have been prosecuted in the Northern District.

Another 26 suspects ( 23 matters) who had already been charged by the U.S. Attorney in another federal district were excluded from the analysis. Upon arrest within the Northern District, these suspects were promptly "removed" to the charging district under rule $\mathbf{4 0}$ of the Federal Rules of Criminal Procedure, and it does not appear from the files we examined that there was ever any basis for prosecution in the Northern District.

The number of "prosecuted" cases in our sample also required some adjustment. Fourteen suspects, in 12 cases, were initially charged in another district, but elected to have their cases transferred to the Northern District pursuant to rule 20 of the Federal Rules of Criminal Procedure, rather than face "removal" under rule 40. Such cases did not represent "local" matters. Although the transfer requires the consent of the U.S. Attorneys in both districts, it is rare that the receiving district objects, since defendants must agree to plead guilty in order to be transferred under rule 20 . These cases are thus not comparable to local cases selected for prosecution, and they were excluded. We also excluded one "prosecuted" case involving two defendants who consented to trial before the U.S. magistrate, because it was unclear whether these defendants would have been prosecuted in the absence of such consent.

ss The offense categories established for the purposes of this project are generally comparable to the categories used in published court statistics. See, e.g., [1975] Admin. OfFice of the U.S. Courts ANN. REP. Table D-5, at 423.

${ }^{36} 18$ U.S.C. § 2312 (1976).

37 The low prosecution rate for civil rights cases may reflect a policy of the Department of Justice that state authorities be encouraged to prosecute such offenses. 


\section{TABLE 3}

Prosecution Rates by Offense for Local Matters Received

\begin{tabular}{|c|c|}
\hline Offense Category ${ }^{\mathbf{a}}$ & $\begin{array}{l}\text { Percentage } \\
\text { Prosecuted }\end{array}$ \\
\hline Violent offenses $b$ & 50 \\
\hline 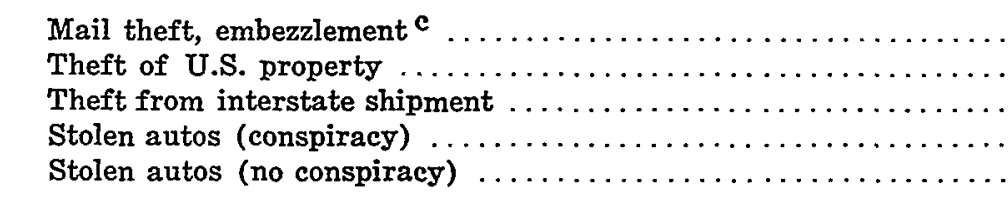 & $\begin{array}{c}51 \\
4 \\
8 \\
100^{*} \\
5\end{array}$ \\
\hline 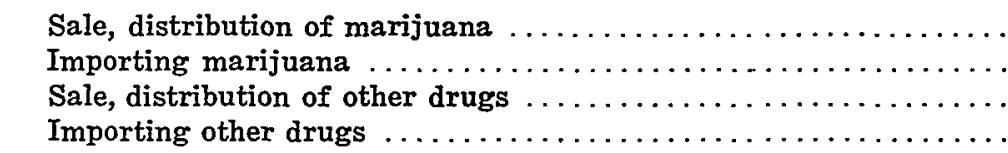 & $\begin{array}{l}40 * \\
2 \\
53 \\
10^{*}\end{array}$ \\
\hline 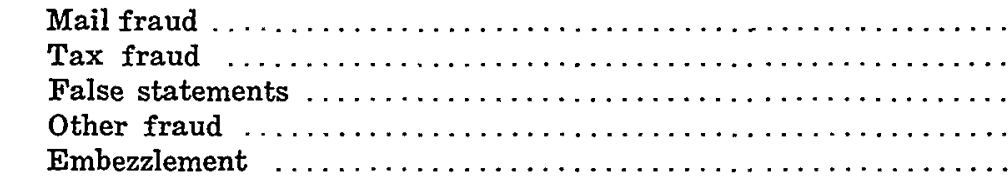 & $\begin{array}{r}21 \\
59 \\
21 \\
7 \\
11\end{array}$ \\
\hline 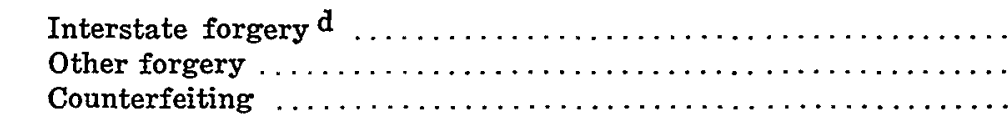 & $\begin{array}{l}12 \\
16 \\
13\end{array}$ \\
\hline 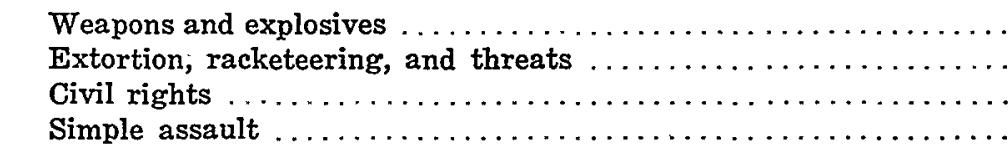 & $\begin{array}{r}24 \\
10 \\
0 \\
0\end{array}$ \\
\hline 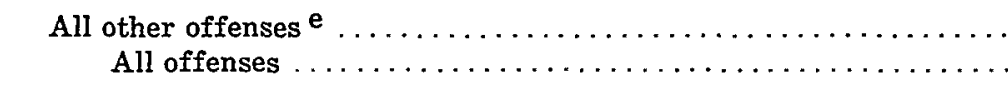 & $\begin{array}{l}12 \\
17\end{array}$ \\
\hline
\end{tabular}

* Percentage based on fewer than 10 cases

Note: Percentages are based on number of matters received in each offense category. Matters neither declined nor prosecuted are excluded.

a Indicates the most serious substantive offense charged, based on maximum authorized sentence.

$\mathrm{b}$ Includes rape, robbery, and aggravated assault.

c Includes theft and embezzlement by postal employees.

d Interstate transportation of forged securities, 18 U.S.C. $\$ 2314$ (1976).

e None of these offenses represents more than $1 \%$ of total matters or defendants received. 
relatively high prosecution rates included violent offenses, mail theft, and income tax fraud..$^{38}$

Of course, one cannot assume that these different offenses all presented an equal proportion of prosecutable cases; perhaps the offenses that show the lowest prosecution rates tend to involve the greatest problems of proof, illegal police procedures, or other defects. Alternatively, it may be that cases involving these offenses typically present attractive alternatives to prosecution that are not available in the case of offenses showing higher prosecution rates. Both of these hypotheses will be examined through analysis of the reasons for declination. ${ }^{39}$

\section{B. Differences in "Magnitude" of the Offense Between Prosecuted and Declined Matters}

As suggested above, the decision to prosecute drug offenses was closely related to both the type and amount of drug involved. Table 4 shows the prosecution rate for each of twelve drug typeand-amount combinations, and a clear pattern emerges: offenses involving heroin were most likely to be prosecuted overall, followed by offenses involving cocaine and marijuana. Furthermore, a different "cutoff point" seems to exist for each drug; no marijuana cases involving less than a pound of contraband were prosecuted. Cocaine cases involving one to two ounces appear to be a borderline category, whereas all cases involving amounts of two ounces or more were prosecuted. As for heroin, it appears that all amounts might lead to prosecution, but the probability of prosecution was directly proportional to the amount involved.

${ }^{38}$ Since income tax matters are pre-screened in the Department of Justice, see note 17 supra, the high prosecution rate among matters received in the Northern District is to be expected.

To a lesser extent, the relative "priority" of the other offenses shown in Table 3 may also reflect different degrees of pre-referral screening. For example, if postal inspectors only refer their strongest cases, while the FBI refers all matters that it investigates, then the differences shown in Table 3 might represent only the efforts of the U.S. Attorney's Office to compensate for differential pre-referral screening; among "comparable" matters received, the prosecutor might have no priorities whatsoever. We could not evaluate this possibility directly, but there is some evidence that Table 3 represents real differences in prosecutor priorities. As previously noted, the initial screening decision in the Criminal Division eliminates about $50 \%$ of all matters received, and it seems likely that this step compensates for many of the differences in pre-referral screening. Nevertheless, when all "immediate declinations" are excluded from the analysis, the offenses in Table 3 show very similar relative rates of prosecution.

39 See text at notes 172-175 infra. 
TABLE 4

Drug Cases Prosecuted

\begin{tabular}{|c|c|c|c|c|c|c|}
\hline \multirow[b]{2}{*}{$\begin{array}{l}\text { AMOUNT } \\
\text { OF DRUG }\end{array}$} & \multicolumn{2}{|c|}{ MARIJUANA } & \multicolumn{2}{|c|}{ CocaIne } & \multicolumn{2}{|c|}{ HeroIN } \\
\hline & $\begin{array}{l}\text { Percentage } \\
\text { Prosecuted }\end{array}$ & $\begin{array}{l}\text { Sample } \\
\text { Size }\end{array}$ & $\begin{array}{l}\text { Percentage } \\
\text { Prosecuted }\end{array}$ & $\begin{array}{c}\text { Sample } \\
\text { Size }\end{array}$ & $\begin{array}{l}\text { Percentage } \\
\text { Prosecuted }\end{array}$ & $\begin{array}{c}\text { Sample } \\
\text { Size }\end{array}$ \\
\hline $\begin{array}{l}1 \text { ounce } \\
\text { or less }\end{array}$ & $0 \%$ & 18 & $0 \%$ & 7 & $30 \%$ & 9 \\
\hline $\begin{array}{l}1 \text { to } 2 \\
\text { ounces }\end{array}$ & - & 0 & $50 \%$ & 4 & $67 \%$ & 3 \\
\hline $\begin{array}{l}2 \text { ounces } \\
\text { to } 1 \text { pound }\end{array}$ & $0 \%$ & 6 & $100 \%$ & 2 & $100 \%$ & 5 \\
\hline $\begin{array}{l}\text { over } 1 \\
\text { pound }\end{array}$ & $30 \%$ & 7 & $100 \%$ & 3 & $100 \%$ & 1 \\
\hline unknown & $0 \%$ & 5 & $\longrightarrow$ & 0 & $0 \%$ & 2 \\
\hline All amounts & $5 \%$ & 36 & $37 \%$ & 16 & $52 \%$ & 20 \\
\hline
\end{tabular}

NOTE: Percentages are based on the number of cases received in each drug-type and amount category, adjusted for differences in sampling fractions. See text at note 30 supra. The "sample sizes" shown in the table, however, represent the actual number of cases, prior to adjustment, and are provided as a gauge of the relative reliability of the individual percentage figures.

A similar pattern emerges when dollar amount of loss is examined, although the extent of overlap between prosecuted and declined cases is much greater. The median dollar loss of declined cases was $\$ 325$, while the median for prosecuted cases was $\$ 1,700$; $42 \%$ of declined cases involved more than $\$ 500$ loss, whereas the comparable figure for prosecuted cases was $77 \%$. As shown in Table 5, these differences also appear within those offense categories for which there are sufficient numbers of cases with known dollar amounts to permit comparisons. Some offenses, however, appear to be considered prosecutable at lower dollar amounts than other offenses. Thus, it appears that the offense category and the dollar amount are independent factors, each of which helps to determine the prosecution priority of a given case. ${ }^{40}$

10 A further criterion suggested by the table below is the presence or absence of a conspiracy or other organized criminal effort; overall, $45 \%$ of matters involving conspiracy charges were prosecuted, whereas only $16 \%$ of nonconspiracy matters were prosecuted. The largest cases (three or more defendants) also tend to receive prosecution priority; this is true even when nonconspiracy cases are considered separately. Apparently two's company, three's a conspiracy! 
TABLE 5

AMOUNT OF Loss

\begin{tabular}{lcccc}
\hline \hline & \multicolumn{2}{c}{ Declined CASES } & \multicolumn{2}{c}{ Prosecuted CASES } \\
\cline { 2 - 5 } \multicolumn{1}{c}{ OfFENSE } & $\begin{array}{c}\text { Median } \\
\text { Amount }(\$)\end{array}$ & $\begin{array}{c}\text { Sample } \\
\text { Size }\end{array}$ & $\begin{array}{c}\text { Median } \\
\text { Amount }(\$)\end{array}$ & $\begin{array}{c}\text { Sample } \\
\text { Size }\end{array}$ \\
\hline $\begin{array}{l}\text { Mail theft (nonpostal } \\
\text { employee) }\end{array}$ & $\$ 225$ & 7 & $\$ 1,050$ & 11 \\
$\begin{array}{l}\text { Interstate forgery } \\
\text { Other forgery }\end{array}$ & $\$ 880$ & 18 & $\$ 1,385$ & 4 \\
Counterfeiting & $\$ 315$ & 23 & $\$ 550$ & 7 \\
\multicolumn{1}{c}{ All offenses } & $\$ 40$ & 10 & $\$ 640$ & 3 \\
\cline { 2 - 5 } & $\$ 325$ & 165 & $\$ 1,700$ & 61
\end{tabular}

IV. Analysis of Stated Reasons for Declination

The data presented thus far have implied both positive and negative criteria for the prosecution of federal charges, but we have a more direct source of information: the file memoranda written by the Assistant U.S. Attorneys to justify nonprosecution. Ideally, one would also want to examine written reasons asserted in favor of prosecution, but no such data source exists. It is often possible, however, to infer positive prosecution criteria from the reasons for declination.

Table 6 summarizes the frequency of specific reasons for declining to prosecute 546 suspects. The percentages shown in the table total to more than $100 \%$, since many declinations involve Footnote 40, continued:

Prosecution Rates of Matters Received, by NUMBer of Defendants aNd Presence or Absence of Conspiracy Charges

\begin{tabular}{l|lccc}
\hline \multirow{2}{*}{ Charges $^{2}$} & \multicolumn{4}{c}{ Number of DeFendants } \\
\cline { 2 - 5 } & One & Two & $\begin{array}{c}\text { Three or } \\
\text { More }\end{array}$ & Total \\
\hline Conspiracy b & $29 \%$ & $20 \%$ & $70 \%$ & $45 \%$ \\
No conspiracy & $16 \%$ & $11 \%$ & $28 \%$ & $16 \%$ \\
Total & $16 \%$ & $12 \%$ & $34 \%$ & $17 \%$ \\
\hline
\end{tabular}

NOTE: Percentages are based on number of cases received in each charge/casesize category.

a Based on initial logbook entries.

b Includes combinations of conspiracy and nonconspiracy charges. 
more than one reason. ${ }^{41}$ The actual total, $170 \%$, means that there was an average of 1.7 reasons per defendant. ${ }^{42}$ Nevertheless, it is meaningful to compare the relative frequency with which different reasons occur. The initial inquiry thus takes the form of the following question: For what proportion of declinations was reason $X$ a factor?

As seen in Table 6, the most common specific reason for declination was the state-prosecution alternative. In order, the next most frequently cited reasons were: small amount of loss by the victims; prior record of the defendant; small amount of contraband, such as drugs or guns; the isolated nature of the defendant's act; and insufficient evidence of a criminal act. In addition, a variety of other factors occasionally moved the Assistant U.S. Attorney to decline prosecution; a total of forty-three different reasons were cited in sample declinations. There were also certain reasons that were never cited, such as the running of the statute of limitations or the existence of an illegally obtained confession. Furthermore, some of the "illegal search" declinations involved searches by state law enforcement officials; thus, our findings suggest that federal law enforcement agencies operate in a highly professional manner. Of course, it is also possible that these agencies simply do not refer matters involving obvious illegality to the U.S. Attorney. ${ }^{43}$

The forty-three specific reasons represented in our sample were too numerous and diverse to permit detailed statistical analysis and presentation, so they were collapsed into ten groups of reasons, as shown in Table 7. "Convictability" reasons were divided into the four groups shown in Table 7 and "policy" reasons were divided into the three listed there. On the basis of the preliminary results shown in Table 6, "prosecution alternatives" were placed in three groups: state prosecution, civil/administrative, and other.

In Table 7, frequencies of reasons given for declinations are listed for the ten groups. ${ }^{44}$ Minor offense appears most frequently,

11 See text at notes 165-66 infra.

42 Forty-four percent of the declinations were based on a single reason listed in Table 6; $42 \%$ were based on two reasons, and $15 \%$ were based on three reasons.

43 See note 11 supra.

4T The average number of reasons per suspect shown in Table 7 is 1.6 , which is slightly lower than that shown in Table 6 (1.7). This "loss" of reasons is the result of ignoring multiple reasons within the same group; a single reason falling within one of the 10 groups is sufficient to bring that group into play. For example, if a prosecution was declined because of both the suspect's age and his prior record (a frequent combination), the reasons are tallied as one declination under defendant characteristics.

One other adjustment reflected in Table 7 should be noted. The group of reasons referred to in Table 6 as "offense characteristics" was relabeled "minor offense," since all of the offense-related reasons discovered in the study concerned the perceived triviality of the offense. 
TABLE 6

Reasons for Declination OF Defendants

\begin{tabular}{|c|c|c|}
\hline Category & Reason & $\begin{array}{l}\text { Percentage of } \\
\text { Defendants }{ }^{a}\end{array}$ \\
\hline \multirow[t]{4}{*}{ Convictability } & $\begin{array}{l}\text { No crime } \\
\text { by anyone } \\
\text { by defendant-intent } \\
\text { by defendant-act }\end{array}$ & $\begin{array}{l}5 \\
5 \\
3\end{array}$ \\
\hline & $\begin{array}{l}\text { Insufficient evidence } \\
\text { to convict anyone } \\
\text { to convict defendant-intent } \\
\text { to convict defendant-act }\end{array}$ & $\begin{array}{r}5 \\
7 \\
10\end{array}$ \\
\hline & $\begin{array}{l}\text { Parties unavailable } \\
\text { defendant unknown } \\
\text { defendant unavailable } \\
\text { defendant fugitive } \\
\text { victim unavailable } \\
\text { victim reluctant } \\
\text { victim not credible } \\
\text { witness unavailable } \\
\text { witness reluctant } \\
\text { witness not credible }\end{array}$ & $\begin{array}{l}8 \\
2 \\
1 \\
1 \\
1 \\
1 \\
* \\
* \\
*\end{array}$ \\
\hline & $\begin{array}{l}\text { Legal bar } \\
\text { statute of limitations } \\
\text { immunity } \\
\text { illegal search } \\
\text { illegal arrest } \\
\text { illegal confession } \\
\text { venue improper } \\
\text { speedy-trial violation }\end{array}$ & $\begin{array}{l}0 \\
* \\
2 \\
0 \\
0 \\
* \\
1\end{array}$ \\
\hline \multirow{2}{*}{$\begin{array}{l}\text { Prosecution } \\
\text { Alternatives }\end{array}$} & & \\
\hline & $\begin{array}{l}\text { State prosecution } \\
\text { Prosecution in another district } b \\
\text { Other charges, this district } \\
\text { Plea bargain } \\
\text { Parole/probation revocation (federal) } \\
\text { Parole/probation revocation (state) } \\
\text { Civil commitment } \\
\text { Givil/administrative remedies } \\
\text { Pretrial diversion } \\
\text { Restitution }\end{array}$ & $\begin{array}{c}26 \\
3 \\
2 \\
* \\
* \\
* \\
0 \\
8 \\
3 \\
4\end{array}$ \\
\hline Policy Reasons & $\begin{array}{l}\text { Offense characteristics } \\
\text { small amount of contraband } \\
\text { small amount of loss } \\
\text { isolated act } \\
\text { no interstate impact } \\
\text { statutory overbreadth }\end{array}$ & $\begin{array}{r}13 \\
18 \\
11 \\
* \\
1\end{array}$ \\
\hline
\end{tabular}


TABLE 6-Continued

\begin{tabular}{|c|c|c|}
\hline Category & Reason & $\begin{array}{l}\text { Percentage of } \\
\text { Defendants a }\end{array}$ \\
\hline \multirow[t]{2}{*}{$\begin{array}{c}\text { Policy Reasons } \\
\text { continued }\end{array}$} & $\begin{array}{l}\text { Defendant characteristics } \\
\text { age (young or old) } \\
\text { no prior record } \\
\text { family hardship } \\
\text { other mitigating circumstances } \\
\text { informer }\end{array}$ & $\begin{array}{r}6 \\
16 \\
* \\
2 \\
2\end{array}$ \\
\hline & $\begin{array}{l}\text { Other } \\
\text { agent recommendation } \\
\text { other district recommendation } \\
\text { Dep't of Justice recommendation } \\
\text { excessive delay (before arrest) } \\
\text { agency misconduct }\end{array}$ & $\begin{array}{l}1 \\
* \\
* \\
1 \\
*\end{array}$ \\
\hline Total & & 170 \\
\hline
\end{tabular}

*Less than $0.5 \%$ but greater than 0.

Average number of reasons per defendant

a Based on total of 546 defendants with known reasons for declination.

b Does not include defendants sought only in another federal district. See note 34 supra.

followed by state prosecution, insufficient evidence, and defendant characteristics. A surprisingly large number of declinations involve the absence of any crime. This might suggest either that federal law enforcement agencies are not engaging in significant pre-referral screening of matters, ${ }^{45}$ or that these agencies and the U.S. Attorney's office do not always agree on what is "criminal."

The figures shown in Table 7 do not distinguish between reason groups that occur alone and those that are cited with other groups, and as Table 8 indicates, the ten reason groups are not equally likely to appear in combination. No crime and state prosecution are cited alone about as often as in combination, and the other two prosecution-alternative groups (civil/administrative and

45 See note 11 supra. 
TABLE 7

Reasons For DecLination OF Defendants

\begin{tabular}{llc}
\hline Category & \multicolumn{1}{c}{ Reason Group } & $\begin{array}{c}\text { Percentage of } \\
\text { Defendants }\end{array}$ \\
\hline Convictability & No crime & 12 \\
& Insufficient evidence & 22 \\
& Parties unavailable & 13 \\
& Legal bar & 4 \\
\hline Prosecution & State prosecution & 26 \\
& Civil/administrative remedies & 8 \\
& Other & 11 \\
\hline Policy Reasons & Minor offense b & 44 \\
& Defendant characteristics & 21 \\
\hline \hline & Other & 3 \\
\hline Average number of reasons per defendant c & 164 \\
\hline
\end{tabular}

a Based on total of 546 defendants with known reasons for declination.

b This category corresponds to the reasons labeled "offense characteristics" in Table 6 supra.

c The computed average differs from the computed average in Table 6 (1.7 reasons per defendant). See note 44 supra.

other) also appear alone with some frequency. On the other hand, minor offense appears alone only $18 \%$ of the time; thus, although this is the most frequently cited reason type (44\%), it is cited alone in only $8 \%$ of all declinations ( $18 \%$ of $44 \%$ ). The other two groups of "policy" reasons are even less likely to be considered a sufficient basis for declination. These findings suggest that policy reasons may be perceived as "weaker" than reasons related to convictability or prosecution alternatives, whereas the latter two categories of reasons are viewed as self-sufficient bases for nonprosecution. Table 8 , however, does not take account of combinations 
TABLE 8

Reasons ALONE aNd in COMBINation

\begin{tabular}{|c|c|c|c|c|}
\hline Category & Reason & 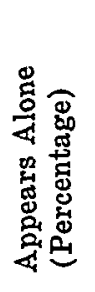 & 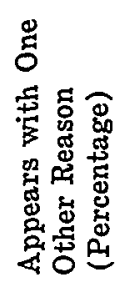 & 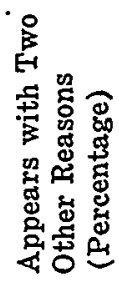 \\
\hline \multirow[t]{4}{*}{ Convictability } & No crime & 53 & 31 & 16 \\
\hline & Insufficient evidence & 29 & 55 & 16 \\
\hline & Parties unavailable & 19 & 67 & 15 \\
\hline & Legal bar & 21 & 68 & 11 \\
\hline \multirow[t]{3}{*}{$\begin{array}{l}\text { Prosecution } \\
\text { Alternatives }\end{array}$} & State prosecution & 46 & 37 & 17 \\
\hline & Civil/administrative remedies & 44 & 45 & 11 \\
\hline & Other & 38 & 41 & 21 \\
\hline \multirow[t]{3}{*}{ Policy Reasons } & Minor offense & 18 & $\therefore 65$ & 16 \\
\hline & Defendant characteristics & 5 & 67 & 28 \\
\hline & Other & 4 & 70 & 26 \\
\hline All reasons & & 45 & 45 & 10 \\
\hline
\end{tabular}

NOTE: Percentages are based on number of defendant declinations involving each reason. Because of rounding, some rows do not total $100 \%$.

within these three major categories of reasons. ${ }^{46}$ It is thus necessary to examine the specific combinations that occur before reaching any conclusions about the relative "strength" of the three reason categories.

\section{A. Reason Combinations}

Reason combinations were analyzed at a higher level of abstraction; that is, all combinations of convictability, prosecution al-

16 For example, a declination based on minor offense plus defendant characteristics would represent one in which policy reasons alone were a sufficient basis for nonprosecution. 
ternative, and policy reasons were studied. ${ }^{47}$ This approach ignores multiple reasons within each of these three major categories. Thus, a declination consisting of two policy reasons and one prosecution alternative is counted as a combination of prosecution alternative reason plus policy reason; a declination with three different policy reasons is counted as a single-reason declination.

\section{TABLE 9}

Categories of Reasons Atone and in Combination

Percentage of Defendants a

Convictability Only 20

Prosecution Alternative Only 22

Policy Reason Only

Convictability + Prosecution Alternative

Convictability + Policy Reason

Prosecution Alternative + Policy Reason

All Three

Total

a Based on total of 546 defendants with known reasons for declination.

As shown in Table 9, policy reasons are the least likely to appear alone, and the four combinations of the three categories are not equally common. Combinations of convictability plus policy and alternatives plus policy are almost as frequent as the incidence with which these factors occur alone, but combinations of convictability plus alternatives and of all three factors are very rare. Thus, it appears that prosecution-alternative reasons are relatively independent of convictability considerations, whereas policy reasons are equally likely to appear alone or in combination with rea-

47 The two-way and three-way combinations of the 10 reason groups with each other were examined, and it was found that almost all possible combinations and permutations occur, although certain combinations are much more common. Over half of the multiplereason declinations involved combinations of minor offense with either insufficient evidence, parties unavailable, state prosecution, or defendant characteristics. The diversity of other combinations, however, was too great to permit detailed analysis of all combinations of the 10 groups of reasons. 
sons from either of the two other categories. In terms of the hierarchy of reasons hypothesized in Appendix A, ${ }^{48}$ this suggests that convictability and prosecution alternatives are equally strong, selfsufficient, and usually mutually exclusive reasons for declination; policy reasons are relatively less likely to be considered sufficient bases for declination. Nevertheless, some declinations are based solely on policy considerations. An examination of the reasons cited in those cases shows that the defendant's noncriminal record is the specific policy reason most often cited, ${ }^{49}$ but the perceived triviality of the offense is the most important policy-reason group: $93 \%$ of the "policy only" declinations involved this factor.

The figures in Table 9 can be combined to show the overall frequency of the three categories: "policy" reasons were a factor in $54 \%$ of the declinations while convictability and prosecution-alternative reasons were present in $45 \%$ and $44 \%$ of the declinations, respectively. Thus, although they are rarely deemed sufficient, policy reasons emerge as the most frequently cited basis for declination. An equally significant finding is that the prosecutor's most traditional and least controversial source of discretion-pretrial screening of weak cases-is a factor in less than half of the declinations in the Northern District.

\section{B. Analysis of Declinations by Offense}

Table 10 shows how the frequency of each of the ten groups of reasons developed earlier ${ }^{50}$ varies by type of offense. The Table reveals that most of the ten groups of reasons occur within each offense type, albeit with differing frequency; at least at this level of abstraction, the reasons are not offense-specific. The frequencies, however, do vary considerably by offense, and this is true even within offense groupings, such as theft and drugs.

In order to appreciate both the "forest" and the "trees," it may be useful to summarize the major patterns shown in Table 10 through specific examples of some fairly "typical" cases in our sample. The danger here, of course, is that no one case is ever truly "typical," and the use of such paradigms may oversimplify or distort the rich diversity of these cases. With that caveat, consider the following varieties of declinations:

Mail theft. This category really includes two quite different

48 See text at notes 164-167 infra.

18 Forty-two percent of the "policy only" declinations involved this reason.

so See text at notes $43-44$ supra. 
TABLE 10

REASONS FOR DECLINATION BY OfFENSE

\begin{tabular}{|c|c|c|c|c|c|c|c|c|c|}
\hline OfFEnse Category & 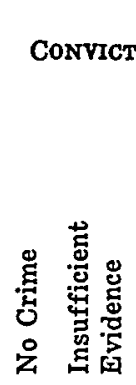 & 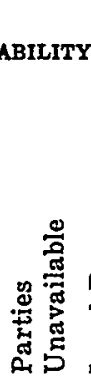 & 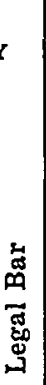 & 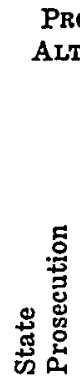 & 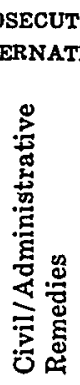 & 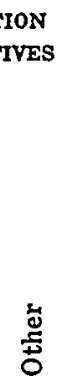 & 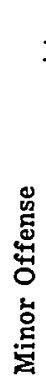 & 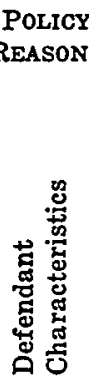 & 迹 \\
\hline Violent offenses* & 25 & 25 & 0 & 13 & 0 & 0 & 25 & 38 & 0 \\
\hline $\begin{array}{l}\text { Theft } \\
\text { mail theft } \\
\text { theft of U.S. property } \\
\text { theft from interstate } \\
\text { shipment } \\
\text { stolen autos (no } \\
\text { conspiracy) }\end{array}$ & $\begin{array}{r}11 \\
13 \\
0 \\
8 \\
\\
\\
13\end{array}$ & $\begin{array}{r}18 \\
0 \\
60 \\
27 \\
0\end{array}$ & $\begin{array}{l}2 \\
8 \\
0\end{array}$ & $\begin{array}{r}38 \\
25 \\
4\end{array}$ & $\begin{array}{r}6 \\
0 \\
12 \\
4\end{array}$ & $\begin{array}{r}11 \\
50 \\
0\end{array}$ & $\begin{array}{l}53 \\
21 \\
64\end{array}$ & $\begin{array}{l}16 \\
13 \\
12 \\
\\
14 \\
\\
25\end{array}$ & $\begin{array}{l}2 \\
8 \\
0\end{array}$ \\
\hline $\begin{array}{l}\text { Drugs } \\
\text { importing marijuana } \\
\text { sale of other drugs }\end{array}$ & $\begin{array}{l}17 \\
15 \\
23\end{array}$ & $\begin{array}{r}5 \\
0 \\
15\end{array}$ & $\begin{array}{l}1 \\
0 \\
8\end{array}$ & $\begin{array}{l}23 \\
17 \\
54\end{array}$ & $\begin{array}{l}3 \\
0 \\
0\end{array}$ & $\begin{array}{l}1 \\
0 \\
8\end{array}$ & $\begin{array}{l}72 \\
80 \\
46\end{array}$ & $\begin{array}{r}53 \\
65 \\
8\end{array}$ & $\begin{array}{l}4 \\
0 \\
8\end{array}$ \\
\hline $\begin{array}{l}\text { Fraud/Embezzlement } \\
\text { false statements } \\
\text { other fraud a } \\
\text { embezzlement }\end{array}$ & $\begin{array}{r}14 \\
16 \\
15 \\
8\end{array}$ & $\begin{array}{r}19 \\
0 \\
17 \\
38\end{array}$ & $\begin{array}{l}1 \\
0 \\
0 \\
0\end{array}$ & $\begin{array}{l}8 \\
0 \\
6 \\
8\end{array}$ & $\begin{array}{r}26 \\
32 \\
33 \\
8\end{array}$ & $\begin{array}{r}11 \\
16 \\
8 \\
17\end{array}$ & $\begin{array}{l}31 \\
47 \\
33 \\
21\end{array}$ & $\begin{array}{l}14 \\
16 \\
13 \\
21\end{array}$ & $\begin{array}{l}6 \\
0 \\
8 \\
8\end{array}$ \\
\hline $\begin{array}{l}\text { Forgery/Counterfeiting } \\
\text { interstate forgery } \\
\text { other forgery } \\
\text { counterfeiting }\end{array}$ & $\begin{array}{l}22 \\
21 \\
18 \\
34\end{array}$ & $\begin{array}{rr}8 & \\
14 & 1 \\
6 & \\
0 & \end{array}$ & $\begin{array}{l}6 \\
1 \\
6 \\
0\end{array}$ & $\begin{array}{l}22 \\
32 \\
18 \\
13\end{array}$ & $\begin{array}{l}0 \\
0 \\
0 \\
0\end{array}$ & $\begin{array}{r}26 \\
18 \\
41 \\
7\end{array}$ & $\begin{array}{l}32 \\
29 \\
29 \\
47\end{array}$ & $\begin{array}{l}29 \\
14 \\
47 \\
20\end{array}$ & $\begin{array}{r}6 \\
0 \\
9 \\
13\end{array}$ \\
\hline $\begin{array}{l}\text { Weapons and explosives } \\
\text { Extortion, racketeering, } \\
\text { and threats } \\
\text { Simple assault }\end{array}$ & $\begin{array}{l}13 \\
34 \\
15\end{array}$ & $\begin{array}{l}13 \\
28 \\
15\end{array}$ & $\begin{array}{l}7 \\
0\end{array}$ & $\begin{array}{r}14 \\
0\end{array}$ & $\begin{array}{r}7 \\
31\end{array}$ & $\begin{array}{r}10 \\
0\end{array}$ & $\begin{array}{l}38 \\
46\end{array}$ & $\begin{array}{l}7 \\
8\end{array}$ & 0 \\
\hline All offenses & 19 & 13 & $4^{-1}$ & 24 & 9 & 12 & 44 & 22 & 3 \\
\hline
\end{tabular}

* Fewer than 10 cases

NoTE: All figures are percentages, based on total matters in each offense category, with known reasons for declination.

Does not include mail or tax fraud. 
offenses. Thefts and embezzlements by postal employees ${ }^{51}$ typically involve very small amounts-a ten-dollar "test letter" sent through by postal inspectors, or a single watch or other item from a package-and such offenders are almost always prosecuted or placed on pretrial diversion. The prosecution and diversion rates for this offense are unusually high, given the small amounts involved. Such high prosecution rates reflect the considerable pressure by the referring agency, and the belief that strict enforcement is necessary to deter other employees, particularly short-term mail handlers hired during the Christmas season. ${ }^{\mathbf{5 2}}$ In contrast, the typical declination for nonemployee mail theft involves theft of packages or welfare checks from mail boxes, in amounts of several hundred dollars; such a case is more likely to be referred to state prosecution.

Theft of government property. ${ }^{53}$ Several typewriters were reported stolen from a government office; after several months of investigation, there were still no suspects.

Theft from interstate shipment. ${ }^{54}$ Defendants were arrested by Chicago police and charged with thefts of appliances worth about four hundred dollars from an airport loading dock. The case was referred to state prosecution.

Auto theft (without conspiracy). ${ }^{ }$Two youths, aged nineteen and twenty, stole a car in Indiana and drove to Chicago, where they were stopped by police. Because only one car was involved and there were no aggravating circumstances such as existence of an organized "ring," the case was referred to state prosecution. In similar cases, the age and absence of prior record of the youths

${ }^{31}$ Charges are usually brought under 18 U.S.C. $\S 1709$ (1976) ("theft of mail matter by officer or employee"). Nonemployee mail thefts are charged under id. § 1708 ("theft or receipt of stolen mail matter generally").

${ }^{82}$ Our six-month sample period included the Christmas season. Although we do not have data for the other six months of fiscal year 1974, we were able to examine computerized data for all matters (other than immediate declinations, which include few mail-theft charges) that were received during the two previous fiscal years. These data suggest that prosecution rates for employee mail theft are much higher during the winter months, whereas other mail thefts receive high priority throughout the year. For fiscal years 1972 and 1973 combined, the estimated prosecution rate for employee mail theft was only $24 \%$; for other mail theft, it was $50 \%$. In our sample, the prosecution rates for these two offense groups were $53 \%$ and $49 \%$, respectively.

s3 18 U.S.C. $\S 641$ (1976).

44 Id. $\$ 659$. This statute contains a rare provision barring federal prosecution if the defendant has already been convicted or acquitted "on the merits" in state court for the "same act or acts." Id. Most deferrals to state prosecution, however, involve pending or unfiled state charges. See text at note 67 infra.

ss 18 U.S.C. $\$ 2312$ (1976). 
would sometimes also be cited in support of declination.

Importing marijuana. ${ }^{58}$ A package containing a half pound of marijuana, sent to a Chicago address from Canada (no return address) was intercepted by customs officials. In cases such as this, prosecution is typically declined because of the small amount, absence of prior drug offenses, state prosecution, or the difficulty of proving that the addressee "knowingly or intentionally import[ed]" the drug. ${ }^{\text {s? }}$

Possession of other drugs with intent to distribute ${ }^{58} \mathrm{~A}$ "controlled delivery," using marked, "official advance funds" was used by a drug agent to purchase one ounce of a mixture containing cocaine. In these cases, the small amount involved is cited as a reason somewhat less often than in the case of marijuana offenses; but state prosecution is cited much more often, usually as the sole reason for declination.

False statement to federal agency. ${ }^{69}$ The recipient of a $\$ 250,000$ loan from a federally insured bank made a willful and materially false statement of his assets and liabilities. The loan was promptly repaid, however (in part because of the threat of prosecution), and the case was declined due to the absence of any actual loss and the effectiveness of the "civil" recovery procedure. "Civil/ administrative" remedies are frequently cited in fraud cases.

Embezzlement. ${ }^{\circ 0}$ A federally insured bank found several thousand dollars missing, but there were no suspects (or insufficient evidence to prosecute the most likely suspects). In another embezzlement involving about five hundred dollars, the defendant, a twenty-two year old teller with no prior record, was placed on pretrial diversion and directed to provide restitution.

Interstate transport of forged securities. ${ }^{\text {B1 }}$ The defendant carried forged securities valued at five hundred to one thousand dollars across state lines; he was referred to state prosecution.

Other forgery. ${ }^{62} \mathrm{~A}$ twenty-five year old male forged the signature on several stolen welfare checks and obtained goods and cash

se 21 U.S.C. \& 952 (1976).

s7 Id. \& 960(a)(1).

s8 Id. $\S 841(\mathrm{a})(1)$.

so 18 U.S.C. $\$ 1001$ (1976).

so Id. § 656 .

-Id. $\$ 2314$. This section provides that interstate transport of stolen "money or property" must involve at least $\$ 5,000$ in order to violate federal law, but there is no jurisdictional minimum for transportation of forged securities, tax stamps, traveler's checks, or tools used for forgery or counterfeiting. Id.

2 E.g., id. § 471 . 
worth about three hundred dollars. Due to his age, absence of a prior record, and the use of pretrial diversion, prosecution was declined.

Counterfeiting. ${ }^{63}$ Defendant passed two counterfeit twentydollar bills. Since he did not appear to be part of any larger operation and it was not clear whether he knew the bills were counterfeit, the case was declined.

\section{Adjusted Prosecution Rates}

The data on reasons can be used to refine our earlier estimates of prosecution rates by type of offense and other known offense characteristics. When "weak cases" (those declined for convictability reasons) are excluded, the overall prosecution rate for matters received rises from $17 \%$ to $26 \%$, but the relative priority of different offenses is not substantially altered. In other words, coincidental variations in the relative strengths of different types of cases do not account for the observed differences in "gross" prosecution rates, as is discussed in more detail in Appendix B. ${ }^{64}$

\section{Analysis of Referrals to State Prosecution}

As shown in Table 6, the most frequent specific reason for declination is the state-prosecution alternative, which was a factor in about one-fourth of the declinations in our sample. Moreover, state prosecution is often deemed a sufficient reason for declination, appearing alone $46 \%$ of the time ${ }^{65}$ Because this is such an important basis for declination and because little is known about the eventual disposition of matters so declined, the study examined this reason more closely so as to determine what kinds of cases are involved, in which state jurisdictions prosecution occurs, and with what final results.

\section{A. Declined Offenses}

As Table 10 demonstrates, prosecution is more likely to be declined in favor of state prosecution for some cases than for others. Such declinations are particularly common in interstate-stolen-

${ }^{83}$ Id. § 472. The sample included some declined matters in which the suspect had used a dollar-bill facsimile in advertising. These matters were so unlike the typical counterfeit case described in the text that we classified them as "miscellaneous" offenses, rather than "counterfeiting."

84 See text and notes at notes 171-183 infra.

${ }^{6}$ See Table 8 supra. 
auto cases not involving any conspiracy aspects. Weapons and drug-sale cases (except those involving marijuana) also show very high rates of declination in favor of state prosecution. Other offenses, such as fraud, embezzlement, and simple assault, are rarely declined for this reason. In some cases, this is because there is no state counterpart of the federal offense. Table 11 lists the variety of federal offenses that are declined in favor of state prosecution. ${ }^{68}$

66

Matters Declined in Fayor of State Prosecution

\begin{tabular}{|c|c|c|c|c|}
\hline \multirow[b]{2}{*}{ FEderat Offense } & \multicolumn{4}{|c|}{ JURISDICTION $^{2}$} \\
\hline & $\begin{array}{c}\text { City of } \\
\text { Chicago } \\
\text { (Percentage) }\end{array}$ & $\begin{array}{l}\text { Other } \\
\text { Cook County b } \\
\text { (Percentage) }\end{array}$ & $\begin{array}{c}\text { Other } \\
\text { Northern } \\
\text { District c } \\
\text { (Percentage) }\end{array}$ & $\begin{array}{c}\text { Out-of- } \\
\text { Stated } \\
\text { (Percentage) }\end{array}$ \\
\hline $\begin{array}{l}\text { Burglary, larceny, stolen } \\
\text { property }\end{array}$ & 45 & 18 & 26 & 82 \\
\hline Drugs & 9 & 18 & 30 & 0 \\
\hline Fraud, embezzlement & 9 & 18 & 0 & 0 \\
\hline Forgery, counterfeiting & 9 & 6 & 26 & 9 \\
\hline Weapons and explosives & 15 & 12 & 4 & 3 \\
\hline Other & 12 & 29 & 13 & 6 \\
\hline Total e & 99 & 101 & 99 & 100 \\
\hline $\begin{array}{l}\text { State Declinations } \\
\text { per Jurisdiction } \\
\text { (Percentage) }\end{array}$ & 47 & 12 & 17 & '24 \\
\hline
\end{tabular}

a Where more than one jurisdiction was involved, the principal place of the most serious offense is shown.

b Includes Berwyn, River Forest, Niles, Calumet City, Cicero, Elmhurst, Forest Park, Wilmette, Franklin, and Justice, Illinois.

c Includes Rockford, Joliet, Roselle, LaSalle County, Will County, DuPage County, Countryside, Darien, Freeport, and Galena, Illinois.

d Includes Indiana, Wisconsin, Michigan, Missouri, Nebraska, South Dakota, Pennsylvania, Florida, Alabama, Texas, California, and the State of Washington.

Because of rounding, some totals do not equal $100 \%$.

The above table summarizes the state jurisdictions in which these cases were to be brought. Not surprisingly, almost half of these declinations involved the Chicago branches of the Circuit Court of Cook County, and over three-quarters were from jurisdictions within the Northern District of Illinois. Out-of-state jurisdictions included a number of Southern and Western states, as well as two Midwest states bordering on the Northern District (Wisconsin and Indiana). There were, however, no downstate Illinois jurisdictions involved, which is probably a reflection of the fact that matters logged in by the Criminal Division for the Northern District of Illinois involve either interstate movement or crimes committed 


\section{TABLE 11}

\section{Matters Declined in Favor of State Prosecution BY OFFENSE}

Federal Offense

Percentage

Violtat offenses

Mail theft . 4

Theft of U.S. property ........................... 1

Theft from interstate shipment $\ldots \ldots \ldots \ldots \ldots \ldots \ldots \ldots \ldots \ldots . \ldots \ldots$

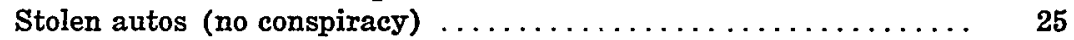

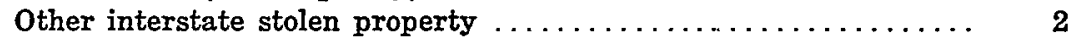

Other theft offenses $\ldots \ldots \ldots \ldots \ldots \ldots \ldots \ldots \ldots \ldots \ldots \ldots \ldots \ldots$

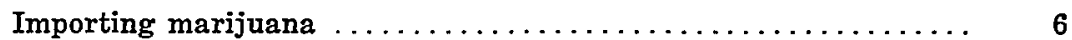

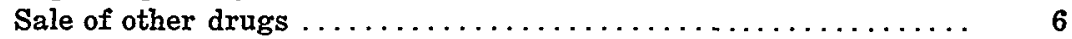

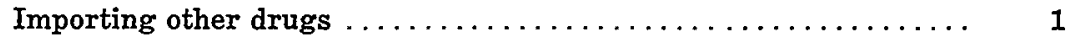

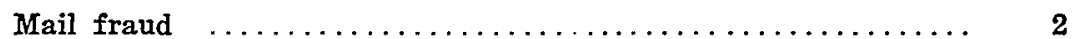

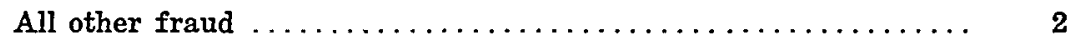

Embezzlement .................................. 1

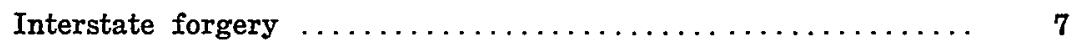

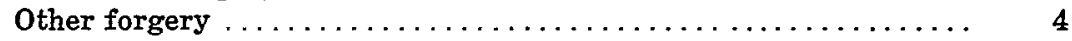

Counterfeiting $\ldots \ldots \ldots \ldots \ldots \ldots \ldots \ldots \ldots \ldots \ldots \ldots \ldots \ldots \ldots \ldots \ldots \ldots$

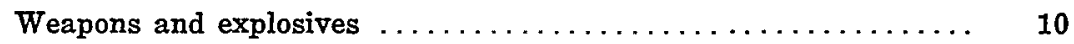

Extortion, racketeering, and threats $\ldots \ldots \ldots \ldots \ldots \ldots \ldots \ldots \ldots$

All other offenses $\ldots \ldots \ldots \ldots \ldots \ldots \ldots \ldots \ldots \ldots \ldots \ldots \ldots \ldots \ldots$

$\begin{array}{ll}\text { Total } & \\ & 99\end{array}$

NoTE: Based on total of 92 matters in which one or more defendants were declined because of state prosecution.

a Because of rounding, total does not equal $100 \%$.

The state offenses for which these defendants were to be charged were not always direct counterparts of the federal charges, although this was the most common pattern (for example, a state

entirely within the Northern District; crimes committed within the Southern and Eastern Districts of Illinois are referred to the U.S. Attorneys for those districts.

As shown in the table, the federal offenses referred to state prosecution are not equally distributed among the state jurisdictions involved. Almost half of the Chicago cases were burglary, larceny, or other theft offenses, primarily thefts from interstate shipments, and over $80 \%$ of the out-of-state cases were theft offenses (all but one of which involved interstate transport of stolen automobiles). Non-Chicago Cook County cases were more likely to involve miscellaneous offenses, whereas other Northern District cases involved relatively high proportions of drug and forgery or counterfeiting offenses. 
charge of auto theft or unauthorized use would be brought in place of the federal charge of unlawful interstate transport). As shown in Table 12, some defendants were charged with a different state offense that grew out of the same incident. In other cases, the defendant had been prosecuted or was expected to be charged for a completely unrelated state offense, usually a more serious one than the federal charge. These latter cases represent a very different theory of declination; rather than shifting prosecution of the crime to state courts, the offense is exempted from federal prosecution on the theory that unrelated state penalties sufficiently punish, treat, or incapacitate the offender. Such declinations thus represent a greater element of policymaking discretion, since the particular criminal episode that was the subject of the federal offense will not be prosecuted at all.

TABLE 12

Defendants Declined in Favor of State Prosecution:

Comparison of State and Federal Charges

Nature of State Charges

Percentage of

Defendants

Similar to federal charges and based

on the same criminal episode

Different from federal charges but arising out of the same criminal episode

Completely unrelated to the federal offense

State charges unknown

Total

100

Table 13 shows the disposition or status of state prosecution efforts noted in the U.S. Attorney's file at the time federal charges were declined. A few defendants had already been convicted in state court (mostly on unrelated charges), and a larger number were involved in pending state cases, but about half had not yet been formally charged. Moreover, many of the defendants "arrested but not charged" were not held in the jurisdiction with the strongest case. ${ }^{67}$ Thus in many instances, particularly interstate-

87 For example, in an interstate-stolen-car case, the state of arrest may only have jurisdiction to file an "unauthorized use" charge, whereas the home state has a legal basis (and 
stolen-car cases, the reference to "state prosecution" seems to represent a statement of policy rather than of fact; that is, such cases ought to be'handled by state rather than federal authorities, even if state authorities do not actually prosecute them.

TABLE 13

Status of State Charges at Time of Frderal Decision to Decline in fayor of State Prosecution

Status of State Charges

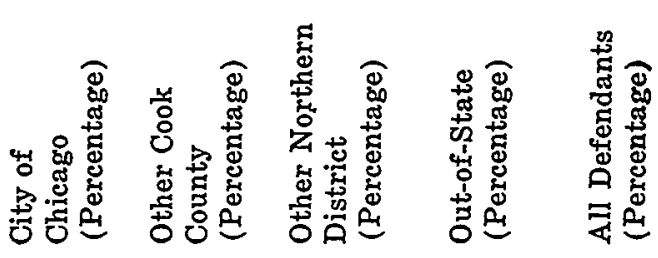

\begin{tabular}{lrrrrr}
\hline Already convicted & 8 & 4 & 29 & 13 & 13 \\
$\begin{array}{l}\text { Prosecution pending } \\
\begin{array}{c}\text { Defendant arrested } \\
\text { but not charged }\end{array}\end{array}$ & 54 & 43 & 16 & 9 & 36 \\
$\begin{array}{c}\text { Under investigation, } \\
\text { known suspect }\end{array}$ & 25 & 26 & 11 & $69^{\mathrm{a}}$ & 31 \\
$\begin{array}{c}\text { Under investigation, } \\
\text { no suspect }\end{array}$ & 4 & 13 & 33 & 5 & 11 \\
$\begin{array}{c}\text { Not indicated } \\
\text { Total b }\end{array}$ & 0 & 7 & 4 & 0 & 2 \\
\cline { 2 - 6 } & 100 & 100 & 100 & 101 & 100
\end{tabular}

NOTE: Sample size:

City of Chicago

Other Cook County

Other Northern District

Out-of-State

All Defendants
64

16

28

23

131

a Over one-half of these defendants were in possession of an automobile stolen in another state when they were arrested by Chicago police. The fact that they were in custody thus does not necessarily signify that the out-of-state authorities were likely to prosecute. See text at note 67 supra.

$\mathrm{b}$ Because of rounding, not all totals equal $100 \%$.

the witnesses) to prosecute the theft itself. See Table 13, note a infra. One study of the disposition of.interstate car thieves arrested by Chicago police found that the most common reason for nonprosecution in Chicago was the refusal of the out-of-state owner of the car to come in and testify. J. Spiotto, How to Succeed in Crime Without Being Tried: A Study of Interstate Auto Theft 16-17 (Apr. 5, 1971) (unpublished paper at The University of Chicago Law School). 


\section{B. State Prosecution Follow-up in Chicago Courts}

In an effort to obtain more complete information on the status of state prosecutions, an attempt was made to follow up these declinations in local courts to see how many were prosecuted, on what charges, and with what results. The pilot study was limited to defendants involved in the city of Chicago, since that jurisdiction accounted for the largest block of defendants and was located closest to our research center. Owing to certain methodological problems, we decided to narrow further our focus to those state charges that were based on the same criminal acts as the federal offenses. ${ }^{68}$ Even with this narrowed focus, a failure to find any record of the defendant in the Circuit Court of Cook County does not necessarily mean an absence of prosecution efforts. Indeed, in a few cases it is possible that the defendant was prosecuted in another jurisdiction. Thus, the estimated prosecution rates reported below are understated, although probably not by a substantial margin.

The results of our pilot follow-up study were as follows: as of June 30, 1976, ${ }^{69}$ eight matters (involving eleven defendants) appeared to have been prosecuted, which represents a state prosecution rate of $22 \%$ for matters and $23 \%$ for defendants. Of the eleven defendants, six were convicted and received sentences ranging from three-years probation to two-years imprisonment. One defendant had been dismissed by the State's Attorney's office, one

${ }^{68}$ As previously noted, prosecution of a defendant is sometimes declined in favor of more serious, or completely unrelated, state charges, see text at notes 66-67 supra, and the U.S. Attorney's files do not always indicate the details of such charges. Tracing the treatment of the same criminal episode in state courts was extremely difficult since our principal sources of information were the defendant's name, the date of offense, and the details of the offense; we did not have access to any unique identifying number for offenders or offenses. Following up on the particular unrelated state charges for which the federal authorities declined prosecution would have been nearly impossible.

Our primary method of access to the state court records was a search of the docket records in the offices of the State's Attorney for Cook County. Whenever a combination of defendant name, offense, and date of filing suggested a possible "match" with a defendant in our sample, we checked the circuit court file for the details of the offense and the offender. It was thus possible to eliminate state court cases that were totally unrelated to the criminal offense charged in our sample. The docket records, as well as those maintained by the circuit court itself, however, were sometimes improperly or illegibly indexed, so it is possible that our manual retrieval efforts overlooked some defendants who were prosecuted in Cook County. In an effort to double-check our findings in the case of defendants arrested by the Chicago police, we requested access to the Police Department's arrest and criminal history records, which generally indicate the disposition of charges related to a given arrest. Despite assurances of confidentiality and anonymity of all findings, the request was denied.

60 This date was 27 months after the last matter in our sample was received by the U.S. Attorney's office. See text at note 30 supra. 
was acquitted, one jumped bail, and two were still pending. These last two defendants had filed an appeal contesting the legality of the search leading to their arrest for possession of heroin. ${ }^{70}$

Since there are instances in which neither federal nor state prosecution is desirable, our inquiry must be refined still further to focus on the declination of federal prosecution in favor of state prosecution where the suspect was apparently convictable. If we exclude from the Chicago sample declinations by the U.S. Attorney based on convictability reasons, the state prosecution rate, for both cases and defendants, actually falls to $18 \% .^{71}$

Due to the many methodological difficulties encountered in the pilot study in Chicago, we did not pursue a thorough follow-up study of state prosecution cases. Moreover, the results of the Chicago study must be viewed as tentative, in light of these methodological problems. Nevertheless, on the basis of these results it seems very unlikely that even one-half of the "state prosecution" declinations are successfully prosecuted in state court. Whether this represents a problem of underenforcement depends upon one's view of optimum enforcement levels. Because we have no comparable data on Cook County prosecution rates by type of offense, amount of loss or contraband, or the like, it is impossible even to say whether the prosecution rates implied by the sample data are typical of state cases in general. If they are typical, one might well inquire whether state prosecution rates are adequate. If, on the other hand, state cases not involving possible federal charges are generally prosecuted at a higher rate, the results of our pilot study may reflect problems that are peculiar to cases with overlapping state/federal jurisdiction. The possibility that these cases tend to "fall into a crack" is worthy of further investigation.

\section{The Policy Implications of the Findings}

This study has shown that the decision to file federal criminal charges is highly selective. Less than one-fifth of the matters received by the U.S. Attorney for the Northern District resulted in the filing of formal charges in U.S. District Court, and the prosecution ratio for matters with a sufficient basis to obtain a conviction

${ }^{70}$ It is interesting to note that the U.S. Attorney declined this case in part because of the questionable search. Similarly, prosecution of the defendant who was dismissed by the state's attorney's office was also declined partly because of an illegal search.

71 The rate falls because state authorities prosecuted a higher proportion of referrals with such convictability problems. 
was only slightly higher than one out of four. ${ }^{72}$ Analysis of declination reasons and the characteristics of declined and prosecuted cases reveals fairly clear-cut criteria that shape the decision to prosecute federal offenses in the Northern District. A large number of declinations were based in whole or in part on evidentiary or legal obstacles to prosecution; this traditional basis for pretrial screening accounted for $45 \%$ of the declinations studied. About two-thirds of the remaining declinations involved the use of an alternative to federal prosecution (most often state or local prosecution), and the rest-18\% of all declinations-were based entirely on policy considerations, especially the perceived triviality of the offense. Triviality was a factor, however, in a much larger proportion of cases- $44 \%$ of the total-and many of the declinations in favor of state prosecution appear to have been based on policy reasons rather than the choice of an effective alternative to federal prosecution. ${ }^{73}$ Looking at the characteristics of particular cases, those involving multiple defendants or conspiracy charges were particularly likely to be prosecuted, and certain other kinds of cases-violent offenses, mail theft, and sales of hard drugs, particularly heroin-also received prosecution priority. Larger amounts of drugs and higher dollar amounts of loss were associated with higher prosecution rates. When the decision to prosecute was examined by screening stages, it was found that the factors above were generally applied in an efficient manner; except for certain declinations involving a magistrate proceeding, cases and defendants were generally weeded out as soon as it was reasonably apparent that the requirements for prosecution were lacking. ${ }^{74}$

These findings raise a number of important policy issues. The frequent dismissal of charges, and the frequent referral of apparently guilty defendants to uncertain state prosecution or to noncriminal alternatives, raises fundamental questions regarding what behavior should be criminally prosecuted and by whom. If agreement can be reached on these difficult issues, there is a further question whether effective mechanisms can be found to regulate prosecutorial discretion so that desirable policies are implemented consistently, efficiently, and fairly. Finally, studies of the exercise of prosecutorial discretion have important implications for the analysis and reform of other criminal justice processes, particularly plea bargaining and sentencing.

72 See text at note 175 infra.

${ }^{73}$ See text at notes 66-67 supra.

74 This is explored in greater detail in Appendix $\mathrm{C}$ infra. 
A comprehensive analysis of the issues raised above is beyond the scope of this article; each is at least a book-length topic. Nor can the data in this study conclusively answer the important empirical questions that underlie these policy issues.

Thus, our research should be viewed as a pilot study, demonstrating the kinds of prosecution policies that more detailed investigations could expect to uncover, and the research methods necessary to document and analyze them. What follows is a brief discussion of the major policy issues, in light of our preliminary findings, and some suggestions for future research.

\section{A. Evaluating Federal Prosecution Rates}

1. Who Should be Prosecuted? Do the highly selective prosecution policies revealed in this study mean that some federal offenses are underenforced? Should Congress immediately appropriate a billion dollars for a "war" on federal crime? Are the existing, limited prosecutorial resources being allocated so as to achieve the greatest benefit? Our data raise, but do not answer, these important issues. It is simply not possible, given our present state of knowledge, to define the "optimum" prosecution rates for different offenses and offenders. For one thing, we lack corresponding data on the rates and reasons for declination by state prosecutors, who are often seeking to control the same criminal behavior. ${ }^{75} \mathrm{We}$ also lack information on the effectiveness of existing state and federal prosecution rates in terms of deterrence, educative effects of the law, and incapacitation or rehabilitation of offenders. Most importantly, we know little about utility of different prosecution rates in achieving these goals. Depending on the shape of the marginal utility curve for federal prosecutions, it may be that only very large increases in prosecution rates would achieve measurably greater effects.

Unfortunately, we are not likely to obtain definitive data any time in the near future. In the absence of such data, however, it should not be assumed that current levels of enforcement are too low, or that additional resources would lead to generally higher prosecution rates. To take the latter point first, it seems clear that the low prosecution rates in the Northern District-in all 94 federal districts, for that matter-are not simply a reflection of re-

${ }^{75}$ Our pilot study of matters referred to state prosecution in Chicago courts suggests that state prosecution rates may also be quite low. See text at notes 68-71 supra. See also authorities cited note 10 supra. 
source scarcity. From 1971 to 1975, the number of Assistant U.S. Attorneys in the Northern District increased $76 \%$, while the total number of cases filed (civil and criminal, including appeals) only increased 12\%; criminal cases filed actually declined $10 \%{ }^{78}$ (For the nation as a whole, manpower increased $64 \%$, total cases filed increased $16 \%$, and criminal filings increased $2 \% .{ }^{77}$ ) In the Northern District, most of this additional manpower was used to support a major campaign against bribery and other forms of public corruption that had not previously been prosecuted by state and local agencies. ${ }^{78}$ Such "special" prosecutions are extremely labor intensive and, judging by the total number of cases filed during the period, they absorbed practically all additional resources devoted to criminal matters. Thus, it seems likely that further increases in federal prosecutorial resources would not substantially alter many of the prosecution criteria we have observed. Trivial cases are not declined for lack of manpower, but because a policy decision has been made that these cases do not require criminal prosecution, at least in federal court. ${ }^{79}$

But how can such selective enforcement policies be justified? Are not the existing enforcement levels so low that they must be deemed inadequate irrespective of what the "marginal utility" data would show? The answer may depend upon one's views of the purposes of punishment. If one believes that punishment is imposed to achieve retribution (and not simply limited by retributive or other normative principles), ${ }^{80}$ then current federal prosecution rates must be considered inadequate. Without doubt, large numbers of federal offenders escape retribution in federal court, and our limited data on referrals to state prosecution suggest that punishment is not provided there either.

The alternative, utilitarian goals of punishment all permit considerable selectivity in prosecution. Incapacitation, for example,

76 U.S. AtTorneys' Office Statistical Report, supra note 27, Tables 1 \& 6; id. (1972); id. (1973); id. (1974); id. (1975).

${ }_{77}$ See authorities cited note 76 supra.

${ }^{78}$ For a description of some of the campaigns in this and other districts, see [1974] U.S. Dep'T of Justice, Atr'y Gen. ANn. ReP. 6-7; Ruff, supra note 13, at 1172, 1176-78, 11841201.

79 It could be argued that "trivial" cases are simply seen as much less important than "special" prosecutions, and that they would be prosecuted, given unlimited resources. We cannot evaluate this claim directly, but the manpower data summarized in the text suggest that the "priority" attached to such cases is so low that it approaches the vanishing point. In any case, resources are limited, whereas the supply of potential "special" prosecutions apparently is not, at least in Chicago.

so See N. Morris, The Future of Imprisonment 58-80 (1974). 
is only necessary if (1) we can predict future criminality on the part of the defendant, and (2) we can also expect that the criminal sanction will prevent (or at least postpone) future crimes. Defendants not meeting these criteria need not, from a purely incapacitative perspective, be either prosecuted or punished. Similarly, the rehabilitative and special-deterrence rationales only require prosecution of defendants who are both likely to commit further crimes and who are "treatable." A general-deterrence rationale might permit even greater selectivity: to the extent that potential violators of the law in question are highly "risk averse"81 with respect to criminal sanctions, a relatively low level of detection and enforcement may provide substantial deterrence. This might be true, for example, among income tax offenders. ${ }^{82}$ As for the "standard-setting" function of prosecution, however, selective prosecution may only be effective if the fact of selectivity is less widely publicized than the sanctions imposed. An occasional prosecution serves to remind the public that certain behaviors are considered "wrong"; but if the public is also aware of similar, unprosecuted cases, the seeming unfairness or inconsistency of society's formal condemnation process may lessen or even eliminate the "moralizing" impact of the occasional prosecution.

The potential unfairness of selective enforcement is itself an important aspect of the system, which may invalidate prosecution policies that would adequately serve utilitarian aims. There are, however, several kinds of selective enforcement. The policy of prosecuting only the most serious violators, which was frequently applied in the Northern District, may be the least offensive example of selective enforcement. Although offenders charged with the "same crime" are being treated differently, most people would view such discrimination as deserved, because the prosecuted offender has committed a more serious offense. A more problematic form of selectivity is totally unrelated to culpability: certain violators are selected because they occupy positions that make them more visi-

81 This concept is used by proponents of economic analysis to account for the differential impact of the same punishment on potential violators. See Becker, Crime and Punishment: An Economic Approach, 76 J. PoL. Econ. 169, 174-79 (1968).

${ }^{82}$ Over 80 million individual income tax returns were filed in 1966, of which about 3 million were audited. From these and other leads, the Intelligence Divisions of the 58 district offices of the IRS conducted about 9,000 preliminary investigations into possible criminal violations, and 2,000 full-scale investigations. These investigations resulted in fewer than 700 criminal cases. President's Comm'n on Law Engorcement and Administration of Justice, Task Force Report: Crime and its Impact-An Assessment 113-15 (1967). See also note 17 supra. 
ble, thus giving the prosecutor more deterrence for the same expenditure. Unfortunately, such selectivity may also result in penalizing defendants for being public officials, accountants, or even for exercising free-speech rights. ${ }^{83}$ A third form of selectivity is not based on any particular criterion: defendants are selected at random because only a few are needed to achieve deterrent aims, or because resources are insufficient to permit prosecution of all offenders. Such "arbitrary" selection raises greater potential risks that the prosecutor will "randomly" select his enemies, but some would say that inconsistency itself is an evil even if the prosecutor chooses blindly. If this view becomes more widely held (and recent "determinate" sentencing reforms suggest that "consistency" is an increasingly important policy consideration ${ }^{84}$ ), it could place major limitations on the use of selective prosecution practices.

The current trend in federal prosecution, however, is toward greater selectivity. ${ }^{85}$ One factor that has accelerated this change is the recognition that noncriminal alternatives to prosecution may serve the aims of punishment as well as or better than criminal penalties. The three-level classification of declination reasons used in this study-convictability, alternatives, and policy-reflected our belief, apparently shared by federal prosecutors in the Northern District, that criminal penalties should be seen as a "last resort" among society's arsenal of available responses to "criminal" behavior. Formal prosecution should only be pursued when there is no strong policy argument against prosecution and no effective alternative means of achieving the goals of prosecution..$^{86}$ The clearest case involves the availability of alternative criminal penalties-for example, revocation of parole or probation, other charges in the same district, charges in another federal district, or state

83 See, e.g., United States v. Catlett, 584 F.2d 864 (8th Cir. 1978) (upholding the policy of singling out vocal tax protesters who openly refuse to file a return).

s4 See, e.g., Twentieth Century Fund Task Force on Criminal Sentencing, Fair and Cerrain Punishment 3-9 (1976).

ss The Department of Justice has increasingly encouraged local U.S. Attorneys to concentrate on major, complex cases. See [1973] U.S. Dep'T of Justice, ATt'y Gen. AnN. Rep. 8. Cf. 24 CRIM. L. Rep. (BNA) 2066-67 (Oct. 18, 1978) (Attorney General Bell listed top four Department priorities as white-collar crime, public corruption, narcotics, and organized crime). The available data on nationwide prosecution rates show a gradual decrease in the period from 1971 to 1978 , even though the number of matters received by U.S Attorneys each year was also decreasing. See Table 1 supra.

${ }^{88}$ Both of the recent national crime commissions strongly recommended increased "diversion" from formal criminal processes. PREsident's Comm'N ON LAw ENForCEMENT AND Administration of Justice, supra note 4, at 133-34; U.S. National Advisory Comm'n on Criminal Justice Standards and Goals, supra note 2, Standard 2.1, at 32. 
charges. Such alternatives will often provide equivalent or greater degrees of incapacitation or rehabilitation, and, for the reasons previously suggested, the deterrent and standard-setting functions of the law may be adequately served by selective prosecution of those defendants for whom alternatives are not available.

Even where no alternative criminal penalties exist, the utilitarian aims of the law may be achieved through the application of civil remedies, administrative regulation, pretrial diversion programs, or restitution. Of course, the availability of an alternative to criminal prosecution does not necessarily mean that prosecution would be inappropriate, but it changes the question: one should then ask whether the added value of the criminal process or sanction is worth any added costs of prosecution. The important point to keep in mind in deciding whether to prosecute is simply that, unless one is a strict "retributivist," any of these alternatives may be valid; the existence of a criminal penalty does not necessarily mean that it must be invoked.

2. Who Should Prosecute? Even if criminal penalties or stigmatization are considered necessary, there is a further question as to which unit of government should administer them. Historically, the "police" power in the United States was considered a function of state and local government, since it was not among the enumerated powers specifically granted to the federal government in article I of the Constitution. ${ }^{87}$ The federal government, however, was soon recognized to have at least the limited police authority "necessary and proper" to carry out its enumerated powers. ${ }^{88}$ Over the years, more and more federal criminal laws were enacted, based on increasingly broad interpretations of federal jurisdiction. ${ }^{89}$ Today, there is substantial overlap between state and federal criminal jurisdiction, but neither Congress nor the states have yet enacted legislative standards to determine when prosecution should be referred to other authorities. ${ }^{80}$ The proposed federal criminal code

${ }^{87}$ The historical development of federal criminal jurisdiction is discussed in Schwartz, supra note 13 , at $64-66$.

ss Id. at 64-65.

89 Id. at 65-66.

90 A few federal crimes include limitations that may reflect a desire to limit federal incursions into state criminal jurisdiction. See, e.g., 18 U.S.C. § 245(a)(1) (1976) (requiring special certification and approval by the Attorney General to prosecute certain civil rights offenses). See also notes 54,61 supra. The federal juvenile delinquency statutes also reflect a strong policy in favor of state prosecution. See 18 U.S.C. $\$ 5032$ (1976) (prohibiting federal court proceedings unless the Attorney General certifies that state authorities (1) cannot or will not take jurisdiction, or (2) do not have adequate programs and services). 
drafted by the Brown Commission in 1970 contained explicit standards to guide federal declinations in favor of state prosecution, ${ }^{91}$ but these provisions were not included in the revised bill subsequently passed by the Senate in $19777^{92}$ and the standards contained in the 1979 Senate version provide only limited guidance. ${ }^{93}$ At the same time, the original code, proposed by the Brown Commission, and to a lesser extent the Senate bills, might actually increase the already broad scope of federal criminal jurisdiction. ${ }^{94}$ Thus, it seems particulariy important to consider what kinds of cases the U.S. Attorney should handle, and which cases should be left to state or local prosecutors.

The clearest case for federal prosecution would seem to involve crimes with no direct state counterpart, ${ }^{95}$ such as federal tax, Selective Service, immigration, customs, perjury in federal court, contempt of federal court, failure to appear in federal court, escape from federal prison, bribery of federal officials, crimes committed at sea or within federal enclaves with exclusive federal jurisdiction, violations of federal administrative or regulatory laws, counterfeiting, or certain civil rights violations. ${ }^{96}$ As the present study indicates, however, these offenses are not always given the highest prosecution priority, even when evidentiary problems are taken into account. ${ }^{97}$ Federal prosecutors appear to give as much or more attention to offenses that are also prosecutable, at least in theory, by state and local prosecutors.

91 See text and note at note 99 infra.

'2 S. 1437, 95th Cong. 1st Sess. (1977). This bill, however, did contain a provision permitting the U.S. Attorney General to suspend state or local jurisdiction over certain offenses (for example, the murder of a federal official). Id. § 205.

${ }^{23}$ See text at note 103 infra.

24 The extent to which the Senate bill, S. 1437, would have created, or at least legitimated, broader federal jurisdiction was a hotly debated question in the hearings held by the House Subcommittee on Criminal Justice. See Federal Criminal Code Reform: The Jurisdiction Issue, [1978] 23 CRIM. L. REP. (BNA) No. 11 (Supp.). For a discussion of the jurisdictional provisions in the Brown Commission Code, see Abrams, Consultant's Report on Jurisdiction, in 1 Working Papers of the National Commission on Reform of Federal Criminal Laws 33-67 (1970).

95 This group of cases corresponds closely to what Professor Schwartz called the federal "self-defensive" criminal jurisdiction. Schwartz, supra note 13, at 66-70. The two concepts, however, are not identical. Some "self-defensive" laws (for example, mail theft) punish acts that could be adequately handled under existing state law. On the other hand, certain offenses that do not directly threaten the federal government need to be prosecuted federally because no state counterpart exists (for example, crimes committed at sea, or within federal enclaves).

o6 For example, deprivation of federal voting rights, as opposed to violations that are often offenses under state laws, such as police brutality.

27 See Tables 3, 10 supra. 
Where concurrent jurisdiction exists, how should federal prosecutors define their authority? What makes an offense a "federal case"? In 1948, Professor Louis Schwartz proposed the following criteria to guide the assertion of such "auxiliary" federal criminal jurisdiction:

[I]n general it can be said that federal action is justified in the presence of one or more of the following circumstances: (1) When the states are unable or unwilling to act; (2) when the jurisdictional feature, e.g., use of the mails, is not merely incidental or accidental to the offense, but an important ingredient of its success; (3) when, although the particular jurisdictional feature is incidental, another substantial federal interest is protected by the assertion of federal power; (4) when the criminal operation extends into a number of states, transcending the local interest of any one; (5) when it would be inefficient administration to refer to state authorities a complicated case investigated and developed on the theory of federal prosecution..$^{98}$

In 1970, the Brown Commission, of which Schwartz was the staff director, recommended that a somewhat different version of these standards be included in the proposed new federal criminal code:

Notwithstanding the existence of concurrent jurisdiction, federal law enforcement agencies are authorized to decline or discontinue federal enforcement efforts whenever the offense can effectively be prosecuted by nonfederal agencies and it appears that there is no substantial Federal interest in further prosecution or that the offense primarily affects state, local or foreign interests. A substantial federal interest exists in the following circumstances, among others: (a) the offense is serious and state or local law enforcement is impeded by interstate aspects of the case; (b) federal enforcement is believed to be necessary to vindicate federally-protected civil rights; (c) if federal jurisdiction exists under section 201(b) [pendent jurisdiction], the offense is closely related to the underlying offense, as to which there is a substantial federal interest; (d) an offense apparently limited in its impact is believed to be associated with organized criminal activities extending beyond state lines; (e) state or local law enforcement has been so cor- 
rupted as to undermine its effectiveness substantially. ${ }^{99}$

It is noteworthy that the Commission version permits federal prosecution of any case, and only restricts declinations, whereas the original Schwartz version appears to start with the premise that state jurisdiction is primary, and that federal jurisdiction is appropriate only if certain conditions are met. ${ }^{100}$

The two versions agree that each of the following factors supports federal jurisdiction: (1) the offense cannot be effectively prosecuted by local authorities; (2) there is a "substantial federal interest" in the prosecution; or (3) the offense involves several states, and transcends local interests. The term "substantial federal interest" may only restate the basic policy question, but the Commission's language, quoted above, provides some additional guidance by listing examples of circumstances that create a "substantial federal interest"-for example, organized criminal activities extending beyond state lines. ${ }^{101}$

Except for the emphasis on organized crime, these criteria do nott correspond closely to existing prosecution policy in the Northern District. The ineffectiveness of state prosecution efforts may account for some filings-for example, charges of bribery and extortion against powerful local officials, or prosecution of large-scale, interstate conspiracies-but it does not guarantee that an offense will be federally prosecuted. Perhaps the fault is with the standards, however, or with the breadth of federal criminal statutes. There are certainly some minor cases that arguably do not belong in federal court, regardless how corrupt or ineffective state systems may be. ${ }^{102}$ The present study suggests that such a de minimis principle is broadly applied in the Northern District, and may account for as much as one-half of the declination rate.

- National Comm'n on Reform of. Federal Criminal Laws, Final Report 19 (1971). See also Abrams, supra note 94.

100 The Schwartz formulation thus discourages federal prosecution in two ways: (1) if a positive factor (for example, state unable to act) is present, federal action is "justified" but not required, as it apparently would be under the Commission code; (2) if the same factor is not present, federal prosecution is barred under the Schwartz formulation, but is still possible under the Commission code.

${ }^{101}$ Some of the other examples provided by the Commission (civil rights and local corruption) appear redundant, given the first principle cited-that declination is inappropriate if the offense cannot be effectively prosecuted by local authorities. See text at note 103 infra.

102 Another problem with the "ineffectiveness" principle is that nonprosecution in state courts could, in some cases, represent a legitimate policy decision by local authorities that prosecution is undesirable-for instance, in obscenity cases. Arguably, there should be some limit to the authority of federal prosecutors to "overrule" such intentional value choices. 
It is unclear whether the other two criteria contained in both sets of standards are applied in the Northern District. The absence of "interstate impact" is almost never cited directly as a reason for declination, ${ }^{103}$ although it is possible that "state prosecution" declinations include many cases seen as purely local. Nor do the declination memoranda speak of "federal interest" in the prosecution. Again, perhaps the fault is with the standards: except for a few offenses directed at federal agencies or programs, it is difficult to say that any crime-even organized crime-involves a peculiarly "federal" interest, let alone a "substantial" one, provided that state and local authorities are able and willing to prosecute. Similarly, why does the fact that an offense "extends into a number of states" justify federal prosecution, if effective state prosecution is available? Both of these formulas probably derive from constitutional concepts that are now outdated; ${ }^{104}$ on a law enforcement policy level, they beg the question. If these two factors are discarded, the rather complex criteria proposed by Schwartz and the Brown Commission can be reduced to two. Federal auxiliary jurisdiction is appropriate when state authorities are unable ${ }^{105}$ or unwilling ${ }^{106}$ to act, and when some minimum level of seriousness is established. ${ }^{107}$ Neither of these criteria is self-defining, of course, but they avoid the use of empty formalisms bearing no relationship to the actual need for federal auxiliary jurisdiction. ${ }^{108}$

${ }^{103}$ See Table 6 supra.

104 Broad expansion of the commerce and other federal powers has almost eliminated constitutional limitations on federal criminal jurisdiction. See Abrams, supra note 94, at 3639; Schwartz, Reform of the Federal Criminal Laws: Issues, Tactics and Prospects, 41 Law \& Contemp. ProB. 1, 18 (1977). In any case, whatever the current or future constitutional limiting principles may be, they need not form the basis for policy decisions about how much of the federal power to exercise.

${ }^{105}$ A major reason why state authorities are unable to prosecute effectively relates to the difficulty of obtaining witnesses from out of state. See Abrams, supra note 94, at 53.

${ }^{108}$ This includes not only cases in which local law enforcement has been corrupted or refuses to protect certain citizens, but also those in which the offense is too minor, from the point of view of each affected state jurisdiction, to motivate state authorities to act.

107 The last clause of this sentence is needed in the unlikely event that existing federal prosecutorial resources are increased substantially. See text at note 102 supra. As a practical matter, however, federal prosecutors are unlikely to be interested in trivial cases.

${ }^{108}$ On the other hand, such formalisms may be much easier to administer, or may cause less day-to-day friction with state and local authorities. But if separate state and federal "spheres of interest" are to be posited, one would think that this should be done along lines that, as much as possible, relate to the need for federal assistance in certain types of offenses. One approach would be simply to define certain areas of law enforcement as "federal," at least above some de minimis level. The current federal emphasis on white-collar, public-corruption, narcotics, and organized crime may reflect a move in this direction. See note 85 supra. 
Whether present practices conform to these two criteria cannot be determined from the data in this study, although the strength of the de minimis policy in the Northern District suggests that this factor predominates. If so, such "skimming" of the most serious cases raises a double problem: local prosecutors and state attorneys general may be capable of handling some of the more serious offenses, while they may be unable to deal with some less serious ones-such as interstate vehicle theft. ${ }^{108}$ At a minimum, the present study suggests the need for greater coordination between state and federal prosecutors, and more research into the specific criteria being used to establish the current division of labor.

As this article goes to press, Congress is considering yet another set of guidelines for the exercise of federal jurisdiction. Senate Bill $1722^{110}$ lists the following "factors" that federal authorities "should consider" in cases involving concurrent state and federal jurisdiction:

(1) the relative gravity of the federal offense and the State or local offense;

(2) the relative interest in federal investigation or prosecution;

(3) the resources available to the federal authorities and the State or local authorities;

(4) the traditional role of the federal authorities and the State and local authorities with respect to the offense;

(5) the interests of federalism; and

(6) any other relevant factor. ${ }^{111}$

Unlike both the Schwartz formulation and the Brown Commission recommendations previously discussed, this latest provision would be purely advisory; it neither requires nor prohibits federal prosecution of any particular case.

As for the "factors" listed in S. 1722, there appears to be a major emphasis on the question-begging "federal interest" concept (factors 2 and 5), and there is no direct mention of the "state ineffectiveness" criterion proposed in earlier standards, though the first and third factors cited may indirectly reflect this criterion. These factors indicate that less severe state penalties might justify

100 The available evidence suggests that these offenses are rarely enforced, even against adults, because out-of-state witnesses will not come in. See note 67 supra.

110 96th Cong., 1st Sess. (1979) (as introduced by Sen. Kennedy, Sept. 7, 1979).

111 Id. $\S 205(\mathrm{~b})$. 
federal charges despite the availability of state prosecution. One can question the value of this provision, however, so long as Congress can increase the penalties for concurrent-jurisdiction offenses. ${ }^{112}$ As for the reverse situation (where the state penalty is greater than the federal), this new provision is unnecessary; if the state is unable to prosecute, federal prosecution seems desirable, and if the state does act, the general rule proposed in this article prevents federal prosecution without resort to the "relative gravity" concept. To summarize, the concurrent-jurisdiction provisions of S. 1722 are useful insofar as they clarify the "state ineffectiveness" rule where state prosecution of a less serious charge is available; beyond this, the bill neither clarifies nor resolves the difficult policy questions involved.

\section{B. Controlling Prosecutorial Discretion}

We now shift from ends to means, or what might be called the "procedural" aspects of the discretion problem: given a set of value choices about which cases should be prosecuted by whom, what mechanisms can be devised to ensure that these choices are consistently and fairly implemented in everyday practice?

The most far-reaching approach would be to redefine the substantive federal criminal law so that it corresponds to either existing or ideal prosecution policy, thus substantially narrowing the scope of prosecutorial discretion. ${ }^{113}$ After all, if certain offenses are almost never prosecuted, why should they be part of the criminal code? In some cases-where the offense is archaic, for example-repeal seems in order, but there are several reasons why it may be difficult to redraft the more typical, partially enforced federal criminal statute. First, to the extent that the "state ineffectiveness" criterion proposed above is applied, substantive law probably cannot define a single, nationwide standard; the specific cases that local authorities cannot or will not effectively prosecute vary greatly from district to district, and also vary over time within any given district. Second, there are certain law enforcement con-

112 See also note 102 supra.

113 'Such an approach might be modeled on the West German system of "compulsory" prosecution, in which prosecutors are required to file charges for any felony for which there is a "sufficient factual basis." See Langbein, Controlling Prosecutorial Discretion in Germany, 41 U. CHI. L. REv. 439, 443 (1974). Such a system presupposes that, except for evidentiary problems, all acts covered by the language of the criminal code should be criminally prosecuted. 
siderations that are independent of prosecution criteria; particularly in the areas of drugs, counterfeiting, illegal weapons, and stolen property, it is often necessary to arrest and interrogate defendants who could easily be prosecuted in state courts, or who fall well below the normal de minimis cut-off point, but who have information about more widespread operations. ${ }^{114}$ For both of these reasons, it may prove quite difficult to draft narrower substantive laws of long-term, nationwide applicability. ${ }^{115}$

Given the apparent necessity for statutes that leave room for the broad exercise of discretion, how can this discretion be kept within acceptable limits? This is an important concern of supervising prosecutors, since they must see that their subordinates are carrying out office policies. Moreover, even in a one-person office, the prosecutor may wish to take steps to ensure both that individual decisions are justified and consistent over time, and that such decisions are perceived by outsiders as proper. Finally, from the perspective of the public, there must be some mechanism by which elected or appointed prosecutors may be held accountable for their decisions.

There are a number of procedural devices that have been suggested as means for controlling prosecutorial discretion, including the use of written reasons for each decision ${ }^{116}$ (with or without dissemination to complainants or defendants); administrative review by supervising prosecutors, ${ }^{112}$ routinely, or upon "appeal" by the victim or defendant; computerized case-management systems; ${ }^{118}$ promulgation of written rules or guidelines for the exercise of discretion; ${ }^{119}$ involvement of defense attorneys in a "pre-charge" con-

114 See text at note 211 infra.

115 These two problems may also limit the feasibility of binding administrative guidelines, at least at the national level. As to the administrative rulemaking approach, see text and notes at notes 134-144 infra.

118 See K. Davis, supra note 1, at 188-214. See also K. Davis, Discretionary Justice in EURope AND AMERICA 73 (1976).

"17 See K. Davis, supra note 116, at 73-74. See also Rabin, supra note 8 (suggesting that the Department of Justice should review prosecution policies in each of the 94 districts, based on quarterly reports of the rates and reasons for declination, by offense).

118 See Watts \& Work, Developing an Automated Information System for the Prosecutor, 9 Ам. CRIM. L.Q. 164 (1970).

119 See K. Davis, supra note 1, at 15-21; President's Comm'n on Law Enforcement and Administration of Justice, supra note 4, at 134; U.S. National Advisory Comm'n on Criminal Justice Standards and Goals, supra note 2, Standard 1.2, at 24; Abrams, Internal Policy: Guiding the Exercise of Prosecutorial Discretion, 19 U.C.L.A. L. REv. 1, 1-25 (1971); Beck, supra note 13, at 311-45. 
ference; ${ }^{120}$ and judicial review of decisions for or against prosecution. ${ }^{121}$

1. The Written-Reasons-and-Review Approach. The office we studied used a system of written reasons, routinely reviewed by supervising prosecutors within the office. Although there were no written office guidelines, and little formal "indoctrination" of new assistants as to office policies, this system appeared to produce fairly consistent ${ }^{122}$ results, without raising any of the problems said to be associated with the use of published guidelines or judicial review, such as greater delay, loss of privacy and confidentiality of investigative files, and lessened deterrence in low-priority cases. ${ }^{123}$ Such a system is also fairly inexpensive. With an annual total of about four thousand matters.declined in the Northern District, one supervising attorney could read all declination memoranda and attached files in two or three working hours per day; ${ }^{124}$ a system of "spot checking" some of the files, to see that the reasons have a sufficient factual basis, would require even less supervisory time and would probably be equally effective. Thus, the proposed use of sophisticated computerized case-management systems to aid in making prosecution decisions ${ }^{125}$ may not be necessary in an operation of this size; the majority of declinations are so self-evident that they are identified on the day of referral to the Criminal Division, and the remaining caseload appears to be sufficiently small, given the available manpower, to permit individualized, case-bycase evaluation by assistants and their supervisors. Although computerized systems can be quite useful for other management purposes, the decision to prosecute can be entrusted to nonelectronic

120 See Ali Model Code of Pre-Arraignment Procedure $\S 320.1$ (1975); President's Comm'n on Law Enforcement and Administration of Justice, Task Force Report: The Courts 7-8 (1967).

121 See text at note 146 infra.

122 There were, however, a few exceptions. For example, one defendant was prosecuted for a mail theft involving a welfare check worth $\$ 157$, whereas prosecution of most nonpostal employee suspects charged with stealing such a small amount were declined. (This case was eventually dismissed on the government's motion.) There may have been other cases of inconsistency that were not apparent from the files we examined, but the number of such cases could not be too large; if it were, we would not be able to recognize the clear patterns of prosecution policy that emerged.

${ }^{123}$ See generally Inmates of Attica Correctional Facility v. Rockefeller, 477 F.2d 375, 380 (2d Cir. 1973).

124 This estimate assumes an average expenditure of five to ten minutes per declination,

18 declinations per day, 220 days per year.

${ }^{128}$ See Watts \& Work, supra note 118. 
brains, at least in a small-to-medium-sized office with a single supervisor. ${ }^{128}$

The use of the reasons-and-review approach, however, has its limitations. For one thing, there are certain reasons that cannot always be verified by reading the file; if the assistant says "Witness $X$ told me she is unwilling to testify," the supervisor will probably not take the time to talk to the witness personally in any but the most serious cases. Still, if supervisors let their assistants know that such double-checking is sometimes done, and that any discrepancies will be dealt with severely, the file review should generally suffice. Another way to keep the assistants honest is to provide the victims and investigating agent with a copy of the declination memorandum, and to encourage them to discuss the case with the supervising prosecutor. ${ }^{127}$

A further limitation of the reasons-and-review approach is that, in the absence of underlying "rules" of decision, ${ }^{128}$ it is difficult for supervisors to base their review on objective criteria. For example, if the reason for declination is "small amount of loss" in an interstate theft case, and the file merely confirms that the estimated loss was $\$ 550$, the supervisor needs a firm rule for deciding whether the assistant's decision was correct. In the absence of such a rule, the supervisor must decide whether or not $\$ 550$ makes such a case "too minor," substituting his or her ad hoc reaction to the facts for that of the assistant. There is thus no guarantee that the supervisor's decisions will be consistent over time, and no way for the assistant to know what will be approved next time. ${ }^{129}$

All this is not to say, however, that a reasons-and-review approach without such rules is worthless, only that the process works more efficiently with them. In fact, in the example above, the supervisor is applying a rule of sorts: a very low dollar amount of loss may make a case unprosecutable. Such a rule-we will call it a nonquantifiable "factor"-does give the assistant some guidance, and promotes consistency in decisions. Over time, a factor may

128 An office with a caseload requiring two or more supervisors to review declinations could present an entirely different situation, since they might very well hold inconsistent policy views.

127 See text at notes 132-133 infra.

${ }^{128}$ See text at notes 134-144 infra.

129 Cf. Zeisel \& Diamond, Search for Sentencing Equity: Sentence Review in Massachusetts and Connecticut, 1977 Am. B. Foundation ResEARCH J. 883, 933 (1977) (arguing that reasons for a judicially imposed sentence are useful only if they provide a "full explanation" for the decision, and "when they refer to operating rules that translate mitigating and aggravating circumstances into points on a sentencing scale"). 
evolve into a rule, as supervisors conclude that the dividing line between declinations and prosecutions tends to fall around $\$ 500$. Moreover, even if the policy-formulation process has not progressed to the stage of articulated factors, they may emerge from the process of reason giving; thus, reasons evolve into factors, and factors evolve into rules.

Another difficulty with the reasons approach arises when there is more than one reason given for the decision. The present study shows that prosecutors frequently articulate two or three distinct reasons for declination, and this is true even when we "collapse" similar groups of reasons together. Such combinations pose problems for prosecutors as well as for researchers, because they are ambiguous: Are any of the reasons considered self-sufficient? Is no one sufficient, meaning that two or more are necessary to support the decision? From a research standpoint, these ambiguities make it harder to state with confidence the real reason for a decision. Similarly, assistant and supervising prosecutors may interpret the stated reasons for a particular decision differently, which interferes with the feedback process by which policy is developed and passed down the chain of command. One solution to this problem is for assistants to cite all reasons that they believe support the decision, but to identify which, if any, are deemed self-sufficient. Supervisors may then return the memorandum with any necessary corrections as to policy errors, even if the decision has been affirmed.

Despite these limitations, the use of written reasons for prosecution decisions, which are routinely reviewed by supervising attorneys, seems the minimum requirement for effective control of prosecution decisions. Without such reasons, there is little basis for any other form of review, whether by higher level prosecutors, such as the Department of Justice, or by the courts. Nor does there appear to be any reason why the affirmative decision to prosecute could not be documented and reviewed in the same manner as declinations were in the Northern District. ${ }^{130}$ The reasons for prosecution will usually (but not always) be the opposite of reasons for declination, in which case the decision to prosecute merely represents the absence of any of the latter reasons. Such a decision, however, should be reviewed by supervising prosecutors just as carefully as

130 At the time of our study, decisions to prosecute were formalized internally by "prosecution memoranda," but these contained discussions of proof requirements and problems rather than policy reasons justifying prosecution. 
declination decisions, and the review process is facilitated by articulation of the reasons for the decision. ${ }^{131}$

Although such reasons are a necessary condition for effective control of prosecution decisions, they may not be sufficient for that purpose. To the extent that supervisors do not take their review job seriously, or wish to conceal the real reasons for these decisions, inconsistency and unfairness are likely to result. Moreover, if the reasons do not develop beyond the level of guiding factors, it may be impossible for even well-intentioned supervisors to determine that abuse or inconsistency has occurred. Finally, the appearance of fairness, as well as fairness in fact, is an important policy goal, and one which may not be achieved through informal selfregulation. Thus it is necessary to consider some of the other regulatory mechanisms listed at the outset.

Given the existing reasons-and-review procedure in the Northern District, it would be a fairly small step to permit defendants and complainants to "appeal" the decision in their case to higherlevel prosecutors. At present, the referring law enforcement agent is generally advised, orally or in writing, of the reasons for nonprosecution. This procedure should be formalized, however; the referring agent should always receive a copy of the declination memorandum. The agent, or his superiors, could then be given the right to appeal the decision to supervising prosecutors, with perhaps a further level of "discretionary review" by the Department of Justice. Such review would help to ensure that the reasons asserted by assistant prosecutors have a valid basis in fact, and that there are no additional factors that ought to change the result. Such appeals would also promote a healthy dialogue between prosecutors and agents, in which the agents become more familiar with the problems and policies of prosecution, while the prosecutors keep in touch with the needs of law enforcement as seen from the street.

Much of the same reasoning would support giving victims and defendants a written statement of reasons for prosecution decisions. But such disclosure of prosecution policy raises several additional problems. First, there are sometimes good reasons for not publicizing such policy-where, for example, selective enforcement of the most serious violations is used to conserve resources. ${ }^{132}$ Sec-

231 It would also be useful if assistant prosecutors were required to cite any pro-prosecution factors in cases that are recommended for declination, and vice versa. Such a complete statement of "aggravating and mitigating" factors would greatly assist supervisors in reviewing screening decisions.

${ }^{132}$ See text at notes $138-140$ infra. 
ond, even if publication itself is not a problem, it is likely that any corresponding right to administrative appeal would be used much more frequently by victims and defendants than by law enforcement agents, since the latter are more familiar with prosecution policy. Finally, in the case of decisions in favor of prosecution, any preindictment appeal raises potential statute of limitations problems, and postfiling appeals may run into speedy-trial problems. Even if the defendant waives any right he or she might have to prompt indictment and trial, there are important public interests in prompt disposition ${ }^{133}$ that would be threatened by prolonged appeals. All of this is not to say that victims and defendants should never be given reasons and administrative-appeal rights, only that it is difficult to make these procedures a firm requirement.

2. Formal Rules. Should prosecutors be required to go further and develop firm rules to guide the exercise of discretion? Such rulemaking is perhaps the most frequently suggested mechanism for controlling prosecutorial discretion. The arguments in favor of this approach have often been discussed in the literature, ${ }^{134}$ and may be summarized briefly as follows: (1) rules aid in the training of new assistant prosecutors ${ }^{136}$ and in the internal review of all prosecution decisions, so that office policy is consistently and efficiently carried out; (2) rules give greater substance to administrative- or judicial-appeal rights, since in the absence of such rules it is difficult for victims or defendants to discover and prove that they have been treated differently; ${ }^{136}(3)$ in some cases, it may also be appropriate for defendants or complainants to challenge prosecution policy itself (as opposed to failures to follow the policy) as being inconsistent with legislative intent or constitutional requirements; (4) rules permit the legislature to know exactly how much of the substantive criminal law is being actively enforced, against which types of offenders, and for what purposes, and this information permits more intelligent and realistic legislative action; (5) rules serve to reassure the public, complainants and

133 See Frase, The Speedy Trial Act of 1974, 43 U. CHI. L. REv. 667, 668-69 (1976).

${ }^{134}$ See authorities cited notes 116,119 supra.

${ }^{135}$ This is particularly important in light of the high turnover rate in most prosecutors' offices. Abrams, supra note 119 , at 6 .

${ }^{136}$ See, e.g., Falk v. United States, 479 F.2d 616 (7th Cir. 1973) (en banc) (defendant successfully made out defense of discriminatory enforcement by showing that he was indicted in violation of a Selective Service policy of not prosecuting for failure to carry a draft card). Unpublished policy is particularly unfair to defendants represented by less experienced counsel who are likely to be unaware of the policy and thus unable to attack or enforce it. See Abrams, supra note 119, at 28. 
defendants that the prosecutor is not above the law; and (6) in the rare cases in which nonprosecution represents de facto decriminalization (such as fornication and homosexuality offenses), potential offenders are entitled to know that their conduct will not be criminally punished, so they need not fear blackmail or harassment.

It will be noted that all of the above arguments, except the first and perhaps the fourth, depend on such rules or guidelines being made public. Yet there are often good reasons not to publish them. ${ }^{137}$ Some of these arguments have been discussed elsewhere, ${ }^{138}$ and need only be summarized here: (1) publication would reduce the legitimate deterrent and moralizing effects of the criminal law, at least in cases in which declination of prosecution were not meant to condone the behavior, but only to conserve resources $^{139}$ or respect federal/state jurisdictional principles; (2) if potential defendants in minor cases knew in advance that they would not be prosecuted, they would cease to cooperate with law enforcement agents in the investigation and prosecution of more serious offenders; ${ }^{140}$ (3) publication inevitably would result in more frequent attempts to invoke judicial review of prosecution policy and decisions, and such review would further clog an already overburdened criminal court system; and (4) if prosecutors knew that their policy would be published, they would be reluctant to formulate it, or to change it once it was formulated. ${ }^{141}$ These are serious problems, and because of them it seems unreasonable to impose an inflexible requirement that all prosecution policy be reduced to published rules. But prosecutors should be encouraged to make public at least the broad outlines of their policy, in order to serve partially the external goals of rulemaking. More detailed disclosure of prosecution policies may be made in camera to the appropriate legislative committee members.

As for the important internal uses of detailed prosecution

138 The extent to which the Freedom of Information Act, 5 U.S.C. $\$ 552$ (1976), may require public disclosure of federal prosecutorial policy statements is considered in Beck, supra note 13, at 345-54. See also Jordan v. United States Dep't of Justice, 591 F.2d 753 (D.C. Cir. 1978) (holding that the Department Charging Manual's rules and guidelines relating to screening and pretrial diversion decisions are not exempt from discovery under the Freedom of Information Act).

${ }^{138}$ See, e.g., Abrams, supra note 119, at 25-33.

139 Id. at 29-31. Not only may the publication of selective enforcement policies lessen the moralizing (or "standard-setting") function of the law, it may also evoke outright disrespect, if such selectivity is perceived as unfair or arbitrary. See text at notes 82-84 supra.

${ }^{140}$ See text at notes 114 supra, 210 infra.

161 See Abrams, supra note 119, at 29, 32-33. 
rulemaking, the major question is feasibility: can rules be formulated that provide useful guidance and structure, without creating excessive complexity or inflexibility in the screening process? The present study suggests that rules are feasible, at least up to a point. Our data suggest that some offenses and types of offenders are almost never prosecuted, ${ }^{142}$ and this fact could certainly be stated in writing and used to train new assistants and guide internal-review processes. It is important, however, to recognize that there are several different types of rules, which differ in their utility as guiding and structuring mechanisms. The strictest form is the mandatory rule: "all conspiracies to distribute heroin will be prosecuted, if the evidence suggests a reasonable likelihood of conviction." The next strictest form is what Professor Abrams calls the presumptive rule: ${ }^{143}$ "cases involving one ounce of heroin or less will normally not be prosecuted, absent unusual circumstances." To the extent that such "unusual circumstances" can be enumerated, of course, such a presumptive rule begins to resemble a mandatory one. If a significant number of unspecified exceptions remain, then the presumptive rule begins to resemble the third prototype, the guideline or factor: "a prior record for the same offense is a factor in favor of prosecution." Such a factor may be further developed, to provide for certain contingencies: "factor $X$ controls factor $Y$ when the two are in conflict," or "factors $A$ and $B$, when both present, may provide a sufficient basis for declination."

The present study reveals examples of each of these prototypes, and there does not appear to be any reason to prevent such rules from being reduced to written form for internal use. Of course, there is always the danger of leaks, and the very idea of "secret law" is repugnant. Nevertheless, the reasons in favor of internal rules, and against routine publication of such rules, seem to require this result.

Over time, the number of mandatory and presumptive rules should increase as policy is refined and developed. There will, however, undoubtedly remain a substantial area of discretion, regulated only by a large number of competing factors that, in their cumulative impact and interaction, produce somewhat unpredictable, case-specific results. This seems to be inherent in the nature

142 Many of these cases become "immediate declinations." See text at notes 189-196 ${ }^{243}$ Abrams, supra note 119 , at 22-24. 
of criminal justice discretion; to the extent that we seek to achieve a variety of goals through the criminal process, while recognizing a large number of moral and social principles, we are forced to make complex judgments involving a large number of imprecise factors. ${ }^{144}$

3. Judicial Review. Perhaps the most radical approach to regulating prosecutorial discretion is to expand the scope of judicial review. Under current law, the courts will almost never intervene to compel prosecution of a given offender. ${ }^{145}$ This reluctance to reverse the declination decision is usually based on separationof-powers doctrines, but it also reflects the practical difficulties of reviewing the sufficiency of the evidence and evaluating the allocation of scarce prosecution resources. In its 1973 report, the National Advisory Commission on Criminal Justice Standards and Goals nevertheless recommended that victims and complainants have recourse to judicial review and that courts order prosecution where the declination constitutes an "abuse of discretion."148 The commentary to this recommendation, however, indicates that such orders would be rare, and an examination of the reasons for declination discovered in the present study suggests that this is an accurate prediction. How often, for example, would the court be able to go behind the record to determine that there was an insufficient factual basis for the reasons the prosecutor had provided? Finally, how can courts review the reasons for declination without risking undesirable publication of prosecution policies?

Given these problems, it seems unlikely that courts will agree to review many declination decisions. ${ }^{147}$ The decision to prosecute, on the other hand, has received somewhat closer scrutiny by the courts, at least where there are allegations that the defendant was singled out on the basis of constitutionally impermissible factors such as race, ${ }^{148}$ deterrence of the exercise of first amendment

${ }^{144}$ See, e.g., Table 6 supra (listing reasons for declination of prosecution).

145 See, e.g., Inmates of Attica Correctional Facility v. Rockefeller, 477 F.2d 375 (2d Cir. 1973). But cf. NAACP v. Levi, 418 F. Supp. 1109 (D.D.C. 1976) (upholding a complaint for mandamus to force federal prosecutors and the FBI to conduct a "thorough and meaningful" investigation of the alleged civil rights violations committed by state officials), dismissed as moot, 76 F.R.D. 134 (D.D.C. 1977).

140 U.S. National Advisory Comm'n on Criminal Justice Standards and Goals, supra - note 2, Standard 1.2 , at 24 .

${ }_{147}$ The strongest case for such review seems to exist when the failure to prosecute involves improper motives: corruption or favoritism toward the defendant, or discriminatory intent directed at the victim(s).

${ }^{148}$ E.g., Yick Wo v. Hopkins, 118 U.S. 356 (1886) (defendants were Chinese). 
rights, ${ }^{149}$ or retaliation for the exercise of certain other rights. ${ }^{160}$ The filing of patently insubstantial charges, to harass the defendant or for other improper reasons, has also been successfully attacked. ${ }^{151}$ The Supreme Court has held, however, that accidental inconsistency is not a denial of equal protection, and it has suggested that even "conscious selectivity" is constitutional if not improperly motivated. ${ }^{162}$

Is there a need for a broader defense of discriminatory enforcement? Specifically, should defendants be allowed to contest their charges on the basis that other, similarly situated defendants have not been prosecuted? The present study suggests that, in the Northern District at least, prosecuted and declined defendants are generally not similarly situated. With a few exceptions, the former have committed more serious offenses, and unless we are willing to expand substantially the scope of federal law enforcement efforts, this de minimis policy seems unlikely to be overruled by the courts. Undoubtedly, there are some examples of clear, inconsistent treatment of identical cases. ${ }^{153}$ As noted previously, this is sometimes intentional: only a small fraction of minor income tax violators are criminally prosecuted, because such selective enforcement is thought sufficient to deter most violators (or more precisely, it is thought that the cost of additional prosecution would outweigh the benefits of additional deterrence).

What, then, of what might be called "unprincipled inconsistency"? Should the courts protect defendants from careless screening, resulting in the filing of weak or trivial charges? Weak cases

${ }^{149}$ E.g., United States v. Falk, 479 F.2d 616 (7th Cir. 1973) (defendant was active as a draft counselor and war protester). But cf. United States v. Catlett, 584 F.2d 864 (8th Cir. 1978) (upholding the policy of singling out vocal tax protesters who openly refuse to file a return).

${ }^{150}$ See Blackledge v. Perry, 417 U.S. 21 (1974) (holding that, in order to reduce the danger of prosecutorial "vindictiveness" against defendants who successfully appeal, prosecutor may not file felony charges in trial de novo of convicted misdemeanant unless such charges could not previously have been brought). See also People v. Walker, 14 N.Y.2d 901, 200 N.E.2d 779, 252 N.Y.S.2d 779 (1964) (new trial ordered, based on evidence that defendant's prosecution for housing violations came shortly after she had exposed certain corrupt practices in the Department of Buildings). But cf. Bordenkircher v. Hayes, 434 U.S. 357 (1978) (refusing to apply the Blackledge "vindictiveness" principle to a prosecutor who filed habitual-offender charges against a forgery defendant who refused to plead guilty).

${ }^{151}$ See Shaw v. Garrison, 467 F.2d 113 (5th Cir.) (enjoined further prosecution of state perjury charges that were brought with no apparent factual basis after the defendant had already been acquitted of equally unfounded charges of conspiracy to assassinate President Kennedy), cert. denied, 409 U.S. 1024 (1972).

${ }^{162}$ Oyler v. Boles, 368 U.S. 448, 456 (1962).

${ }^{163}$ See note 122 supra. 
do not appear to be a serious problem, at least in the Northern District. Prosecutors are generally motivated to maintain the highest possible conviction rate, based on cases filed, since this statistic more than any other is taken as the measure of prosecutorial effectiveness. There are also important practical considerations: high screening and conviction rates tend to encourage defendants to plead guilty, thereby conserving limited resources. Thus, even without any judicial review (beyond determination of probable cause), prosecutors have an incentive to screen out weak cases at the earliest possible stage. The result in the Northern District is a very high declination rate and a very low rate of dismissal or acquittal after the filing of formal charges. The conviction rate for the prosecuted defendants in our sample was $91 \%$, and on a case basis it was even higher: at least one defendant was convicted in $93 \%$ of the cases filed.

Similarly, prosecutors are motivated to avoid wasting scarce resources on defendants when policy reasons indicate that prosecution is inappropriate or unnecessary. In particular, prosecutors want to keep their average sentence-severity rates high ${ }^{154}$ to demonstrate their effectiveness. This tends to minimize filings in trivial cases.

\section{The Broader Issues of Prosecutorial Discretion}

The magnitude of federal prosecutorial discretion and the inherent difficulties in closely regulating the filing decision have major implications for any attempts to reform later, more visible areas of criminal justice discretion. Thus, attempts to give the courts greater control over which defendants are admitted to pretrial diversion programs ${ }^{155}$ are of limited utility if prosecutors retain broad, uncontrolled charging powers. Given these powers, prosecutors can decline or dismiss all charges if the court refuses to permit diversion, and they can prevent the court from diverting certain defendants by charging offenses too serious to allow diversion under the applicable program standards. ${ }^{158}$ Similarly, speedy-trial

${ }^{154}$ Cf. Landes, An Economic Analysis of the Courts, 14 J. L. \& EcoN. 61, 63 (1971) (assuming that prosecutors will seek to maximize the number of convictions, weighted by their sentence lengths).

${ }_{185}$ E.g., S. 1819, 95th Cong., 1st Sess. $\$ 5$ (a) (proposed Federal Criminal Diversion Act of 1977). The proposal required the approval of a judge or magistrate prior to entry into any diversion "program," as defined in section $3(2)$ of the bill.

1s6 See People v. Campbell, 46 Cal. App. 3d 799, 120 Cal. Rptr. 330, 334 (1975) (refus- 
reforms ${ }^{157}$ must take into account the ability of the prosecutor to manipulate the events, such as arrest, that trigger statutory time limits; prosecution delay of these events can produce "compliance" with the time limits without actually reducing real delays. ${ }^{158}$

Attempts to abolish or regulate strictly plea bargaining practices ${ }^{158}$ also presuppose that we can effectively control the earlier, less visible decision to file charges. Without such control, prosecutors can avoid plea bargaining restrictions in a number of ways: defendants thought likely to demand trial can be charged with more serious or more numerous offenses; prosecutors can substitute "pretrial diversion bargaining," at least in cases suitable for probation sentences; and "uncooperative" defendants (and their attorneys) who insist on trials can receive less favorable treatment in subsequent cases, or on other pending charges. In this study we have focused primarily on the decision whether to file any charges, but the decision concerning selection of charges-which is crucial to the plea bargaining process-is at least as complex and difficult to regulate. If the filing and charging decisions cannot be regulated more closely than they are at present, the imposition of strict, external limitations on the visible forms of plea bargaining may not substantially improve matters, but it is certain to make the remaining discretion less visible.

Recently proposed mandatory or "determinate" sentencing reforms ${ }^{\mathbf{1 6 0}}$ may also have limited utility given the extensive nature of prosecutorial discretion in the system. If a precise sentence or one within a narrowed range must be imposed on and served by those convicted, the discretion that was previously shared by prosecutors, judges, and parole boards will simply be exercised exclusively by the prosecutor. ${ }^{161}$ Perhaps the most extensive scenario would be a combination of plea bargaining "abolition" and determinate sentencing. In that case, judges would not even share power through

ing to review the prosecutor's threat to charge a nondivertible offense if the defendant moved for diversion).

${ }_{157}$ E.g., Speedy Trial Act of 1974, 18 U.S.C. $\S \S 3161-3174$ (1976).

158 See Frase, supra note 133, at 678-79, 684-86.

169 See note 2 supra.

${ }^{260}$ See note 3 supra. Such reforms have now been enacted in several states. See, e.g., California Uniform Determinate Sentencing Act of 1976, Cal. Penal Code §§ 1168-1170.6 (West Supp. 1979).

161 See Alschuler, Sentencing Reform and Prosecutorial Power: A Critique of Recent Proposals for "Fixed" and "Presumptive" Sentencing, 126 U. PA. L. REv. 550 (1978); F. Zimring, Making the Punishment Fit the Crime: A Consumer's Guide to Sentencing Reform 8-13 (1977) (Occasional Papers, The University of Chicago Law School). 
the plea bargaining process; except for the power of judges and juries to acquit, prosecutors would control the entire outcome through exercise of their filing and charging discretion. Whether this would be better or worse than the existing system depends on one's view of the respective competence of prosecutors, judges, and parole boards in a given jurisdiction; "three discretions may be better than one."162

All of this does not mean, of course, that reforms of pretrial diversion, speedy trial, plea bargaining, and sentencing should be abandoned. But such reforms must respect the immense residual powers of the prosecutor, and avoid drastic changes that would simply drive discretion underground. Reforms that attempt to regulate, but not abolish, discretion stand a better chance of producing real long-term change, at least if they are supported by the key figure in criminal justice administration, the prosecutor. Professor Zimring has called the prosecutor "the black hole of criminal justice." Our data suggest that, in the federal system at least, this is an apt metaphor; the huge discretion of the U.S. Attorney can distort or swallow up all but the most massive reform efforts.

\section{Conclusion}

This study reveals that the prosecutorial discretion of the U.S. Attorney is vast and unchecked by any formal, external constraints or regulatory mechanisms. Yet the prospects for effective and efficient external controls over prosecutorial decisions seem slight; the judgments involved are complex and unsuited to judicial review, and even the formulation and publication of guidelines poses substantial difficulties.

Such broad discretion raises important, unresolved policy questions as to what behavior should be criminally prosecuted, by what jurisdictional authority. The data also suggest that recent attempts to formalize or restrict discretion in the areas of pretrial diversion, speedy trial, plea bargaining, and sentencing may only serve to shift the locus of discretion back to the prosecutor's filing and charging decisions, which may be even harder to control.

Yet, at the same time, the study suggests that there are effective mechanisms short of judicial review or public rulemaking that can regularize and improve prosecutorial discretion. The office we studied uses an internal regulatory procedure whereby the reasons

${ }^{162}$ F. Zimring, supra note 161, at 12. 
for each declination of prosecution are reduced to writing and reviewed by supervising prosecutors. This procedure appeared workable and effective in producing clear patterns of office prosecution policy, and it should be adopted as standard office procedure by all prosecutors. Such a "reasons-and-review" system serves to centralize responsibility for prosecution policy, and it forms the basis for the gradual development of more precise rules and guidelines. This approach does not, of course, guarantee good results under all circumstances. At our present level of regulatory technology, much depends on the ability and good intentions of the prosecutor, and any mechanical faith in a particular process seems misplaced. Nevertheless, if more prosecutors' offices implement such internal procedures, and studies such as this one are replicated in other federal and state jurisdictions, we may begin to develop a clearer understanding of how to formulate and enforce sound prosecution policy. 


\section{Appendix A: The Development of Reasons for Prosecutorial Declination}

Previous studies of prosecutorial discretion have suggested that the reasons for nonprosecution fall into roughly two classes: those that relate to the ability to obtain a conviction given the state of the evidence and the criminal law, and those that relate to the desirability of prosecution and conviction in a particular case or type of case. ${ }^{163}$ This general distinction was adopted for purposes of the present study, but the second category was subdivided into two categories. The first includes those prosecutions that were declined because other measures were being taken to punish, treat, or otherwise deal with the offender. Such prosecution alternatives include pretrial diversion or deferred prosecution, restitution, prosecution by state or other federal authorities, civil or administrative remedies, parole or probation revocation, and civil commitment. In addition, the dropping of charges because of a plea bargain, or simply because other pending charges are considered sufficient, also represents an alternative to prosecution of the present matter.

The second subdivision contains the purest form of prosecutorial discretion-declinations based on policy. If the evidence would support a conviction, and no alternative to prosecution is being pursued, it is clear that the prosecutor is making a policy decision concerning the desirability of doing something about conduct that constitutes at least a technical violation of the law. Such policy considerations may relate to the character of the suspect, such as age or prior record, or the nature and seriousness of the particular offense. Other policy reasons that weigh against prosecution include the recommendation of other officials, the defendant's status as an informer or witness, excessive delays in prosecution, ${ }^{164}$ and the existence of law enforcement or government

${ }^{183}$ See, e.g., F. MrLlER, supra note 8, at 3-7. A major source of guidance in the development of the categories was P. Greenwood, S. Wirdhorn, E. Poggio, M. Strumwasser \& P. DE LEON, supra note 10, Table 42. Many specific reasons were drawn from previous studies of federal prosecutorial discretion. See Kaplan, supra note 13; Rabin, supra note 8; Schwartz, supra note 13. See also A.B.A. Project on Standards for Criminal Justice, Standards Relating to the Prosecution Function and the Defense Function 92-98, Standard 3.9 \& Commentary (Approved Draft 1971); California District ATrorneys Ass'N, Uniform Crime Charging Standards (1974); National District Attorneys Ass'n, National Prosecution Standards Standards 8.2, 9.3, 11.3 (1977); U.S. National Advisory Comm'n on Criminal Justice Standards and Goals, supra note 2, Standard 1.1.

104 Some declinations based on excessive delay involved arrested defendants; these were included in the "convictability" category because defendants would be entitled to move for dismissal for violation of the sixth amendment speedy-trial guarantee, see Strunk v. United States, 412 U.S. 434 (1973). Other declinations based on this reason, however, involved sus- 
misconduct that would be brought to light by prosecution and trial.

The convictability category can also be subdivided into several major groups of reasons. First, prosecution might be declined because of the complete absence of a necessary act or mental state required for criminal liability-so that no crime was committed. Second, even if the suspect's behavior appears to have been criminal, thiere may be insufficient evidence of the criminal act or the criminal intent to establish his guilt in court. A frequent cause of such insufficiency is the absence or unavailability of the parties-the suspect, victim, or a key witness. These reasons were included within a third group entitled "parties unavailable." An attempt was also made to distinguish between physical unavailability, reluctance to testify, and credibility problems. A fourth group of convictability reasons was created for those situations in which the applicable statute of limitations, an immunity grant, or some form of illegal procedure, presents a legal bar to successful prosecution.

The categories of reasons can be viewed as constituting a logical hierarchy, in which the presence of a "higher order" reason should constitute a sufficient basis for a declination of prosecution. Thus, if there is insufficient evidence to convict a defendant, there should be no need to consider alternatives to prosecution or additional policy reasons for not prosecuting; indeed, it may be improper to steer innocent or unconvictable defendants into prosecution alternatives such as pretrial diversion. Declination for lack of a prosecutable case is perhaps the least controversial basis for declining to prosecute, and such reasons are in some sense "stronger" than either prosecution alternatives or policy reasons. Conversely, if prosecution alternatives or policy reasons are cited, either alone or in combination with each other, this should imply that the case was otherwise prosecutable. Finally, there is a sense in which a prosecution alternative is a "stronger" reason than a policy reason for nonprosecution. If something else is being done to punish or deal with the defendant or his crime, then the defendant is not getting off free and clear.

The three categories of reasons, however, are not always mutu-

pects not yet arrested, who were thus not covered by the sixth amendment, United States v. Marion, 404 U.S. 307 (1971). These cases did not appear to involve lost witnesses or other specific evidentiary problems that could have been caused by delay in prosecution. Apparently, the U.S. Attorney simply felt that it was inappropriate to press stale charges. Accordingly, such cases were classified as "policy" declinations. See Table 6 supra. 
ally exclusive. For example, a case that is marginally prosecutable, despite evidentiary problems, might be declined because of the availability of a strong prosecution alternative such as parole revocation, and in such a case both convictability and alternative reasons might be cited. ${ }^{168}$ Similarly, many of the policy reasons that weigh against invoking formal criminal penalties also support the use of alternatives such as pretrial diversion; the appearance of policy reasons in conjunction with prosecution alternatives might simply represent reasons for use of the alternative. Finally, one might predict that in a close case there would be a tendency to invoke as many reasons as possible. As shown in the article, ${ }^{168}$ the use of multiple reasons is quite common, and presents certain practical difficulties in analysis and presentation of the research results. For example, it is possible to state the number and percentage of declinations in which a given reason or category was present, but the total cases and percentages arrived at by this means will always exceed the total sample, due to the multiplereason cases. ${ }^{167}$

The observed variation in number of reasons per declination raises an important methodological issue: How reliable are the reasons asserted in these file memoranda? Can we take the word of the Assistant U.S. Attorney that a given case did or did not involve an evidence problem, or the existence of a prosecution alternative? To a large extent, these questions are unanswerable, but the following observations can be made. First, it is clear that these file memoranda were written entirely for the purposes of internal office administration; neither the assistants involved nor their supervisors had any reason to expect that their work would ever be "audited" by outsiders. Second, since no lawyer wants to be "reversed on appeal," there is reason to believe that the assistants would cite as many reasons as possible to justify their recommendation of declination. ${ }^{188}$ On the other hand, the assistants and supervisors involved did not have a checklist of reasons and reason categories

${ }^{185}$ Such combinations turned out to be quite rare in our sample. See text at note 48 supra.

${ }^{188}$ See text at notes $41-42$ supra.

${ }^{287}$ See Table 6 supra; text at note 42 supra.

168 The immediate declinations present a slightly different situation, since a tentative decision to decline had already been made before assignment to the assistant. We discovered, however, that immediate declinations actually involved a larger number of reasons per case than did later or magistrate declinations, so it appears that the assistants took their job seriously, and presented a thoroughly documented justification for nonprosecution. See Table 23 infra. 
before them, and the failure to cite a particular reason does not necessarily mean that it could not have been cited, only that it was not considered necessary in order to justify the declination decision. In light of the first two observations, however, it seems likely that the omitted reasons were less important than those cited. Given the hierarchy of reasons hypothesized above, ${ }^{160}$ we would expect "convictability" reasons to be cited whenever applicable and policy reasons to be underreported.

It is conceivable that assistants might cite reasons that were not actually justified in the particular case, and that the supervising attorney could not check even if he reviewed the entire contents of the attached file jacket. But, since the facts of the case are presumably well known to the referring agent, any serious distortions could result in complaints to supervising attorneys and exposure of the "cover-up." Thus, we believe that the declination reasons we have observed are a reliable indication of the major considerations that led to nonprosecution of these matters.

Not all declinations in our sample had documented reasons, however. Sometimes we were unable to find the U.S. Attorney's file, and in other cases the file did not contain a declination memorandum. Although it was often possible to guess the reasons for declination, based on other materials in the file, coding of such apparent reasons was likely to be highly subjective and it was also impossible to be sure that all relevant facts were shown in the file. Hence, these cases have been treated as missing data.

Approximately $16 \%$ of the declined matters in our sample had unknown reasons for declination. These cases were examined carefully to determine whether they fell disproportionately within any offense category, crime pattern, or defendant type. A few offenses were found to be particularly likely to have missing data. The outstanding example was civil rights cases, typically involving charges of police brutality in connection with an arrest of the complainant by local police; fully $100 \%$ of the civil rights matters in our sample (twenty-eight cases involving forty-eight defendants) had missing files. ${ }^{170}$ Matters involving tax fraud and mail fraud were also likely to have unknown reasons. All together these three offenses accounted for $48 \%$ of the defendants with missing data.

169 See text at notes 163-165 supra.

170 During the period covered by this study, all civil rights matters were handled by a supervising attorney, presumably because they involved highly sensitive relationships between state and federal government. The declination decisions in these cases were apparently not subject to formal review by higher-level attorneys within the office. 
Other than these offenses, there were no discernible differences between the cases with reasons and those without. Thus, in the analysis in the article, it was assumed that the cases with known reasons adequately represent the total sample, except for the three types of offenses mentioned above. 


\section{Appendix B: Adjusted Prosecution Rates}

As noted in the article, ${ }^{171}$ we cannot necessarily assume that different offenses present the same proportion of prosecutable cases. Consequently, "gross" prosecution rates do not necessarily reflect differences in prosecution policy. Analysis of reasons for declination of these different types of offense can reveal whether in fact cases with a low prosecution rate tend to involve an unusually large proportion of convictability problems or the existence of attractive prosecution alternatives.

Table 14 presents this analysis for sixteen of the twenty-two offense categories analyzed in the article. ${ }^{172}$ The left-hand column in Table 14 reproduces the gross prosecution rates reported in Table 3, and the middle three columns break down the reasons for declination of cases within each offense category. ${ }^{173}$ Thus, for example, $25 \%$ of the declinations for mail theft involved at least one convictability problem; $68 \%$ involved an alternative to prosecution; and $8 \%$ involved only policy reasons.

These frequencies demonstrate that the reasons asserted for declination vary significantly by offense. As suggested in the article, ${ }^{174}$ some offenses with very low prosecution rates involve a high proportion of convictability problems-for example, thefts of government property, thefts from interstate shipments, embezzlement, counterfeiting, and extortion. Dyer Act cases without a conspiracy charge seem to be prosecuted infrequently because of the widespread use of a prosecution alternative. Several other offenses with low prosecution rates, however, do not show such a pattern-for example, importing marijuana or other drugs, and simple assaults. Moreover, several offenses with relatively high prosecution rates also reveal a large proportion of convictability problems or prosecution alternatives. Thus, it does not appear that convictability problems or the availability of alternatives to prosecution account for the differential prosecution rates shown in Table 3.

The right-hand column in Table 14 shows what happens if we adjust prosecution rates by excluding all declinations involving

172 See text at notes 38-39 supra.

172 The six offenses omitted in Table 14 either involved no declined cases (for example, stolen car, conspiracy offenses) or an insufficient number of declined cases with known reasons for declination (for example, civil rights violations).

${ }_{173}$ In multi-defendant cases, the reasons given for declining the "lead" defendant were used. There were relatively few cases with different reasons for individual defendants.

174 See text at notes 38-39 supra. 
TABLE 14

Prosecution Rates and Categories of Reasons for Declination

\begin{tabular}{|c|c|c|c|c|c|}
\hline OFFENSE CATEGoRy ${ }^{a}$ & $\begin{array}{l}\text { Gross Prosecution } \\
\text { RAte (Percentage) b }\end{array}$ & 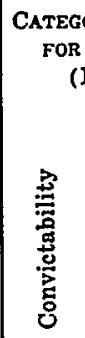 & 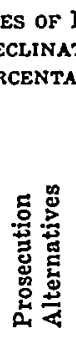 & 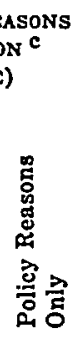 & $\begin{array}{l}\text { Adjusted Prosecution } \\
\text { Rate Excluding Weak } \\
\text { Cases (Percentage) d }\end{array}$ \\
\hline Violent offenses & 50 & 50 & 13 & 38 & 64 \\
\hline $\begin{array}{l}\text { Mail theft } \\
\text { Theft of U.S. property } \\
\text { Theft from interstate } \\
\text { shipment } \\
\text { Stolen autos (no } \\
\text { conspiracy) }\end{array}$ & $\begin{array}{r}51 \\
4 \\
8 \\
5\end{array}$ & $\begin{array}{l}25 \\
68 \\
\\
55 \\
\\
16\end{array}$ & $\begin{array}{l}68 \\
11 \\
\\
35 \\
\\
63\end{array}$ & $\begin{array}{r}8 \\
22 \\
\\
10 \\
\\
23\end{array}$ & $\begin{array}{r}57 \\
11 \\
\\
17 \\
\\
6\end{array}$ \\
\hline $\begin{array}{l}\text { Importing marijuana } \\
\text { Sale of other drugs }\end{array}$ & $\begin{array}{r}2 \\
53\end{array}$ & $\begin{array}{l}15 \\
38\end{array}$ & $\begin{array}{l}17 \\
53\end{array}$ & $\begin{array}{r}69 \\
8\end{array}$ & $\begin{array}{r}2 \\
65\end{array}$ \\
\hline $\begin{array}{l}\text { False statements } \\
\text { Other fraud } \\
\text { Embezzlement }\end{array}$ & $\begin{array}{r}21 \\
7 \\
11\end{array}$ & $\begin{array}{l}36 \\
50 \\
80\end{array}$ & $\begin{array}{l}33 \\
41 \\
20\end{array}$ & $\begin{array}{r}32 \\
9 \\
0\end{array}$ & $\begin{array}{l}29 \\
13 \\
38\end{array}$ \\
\hline $\begin{array}{l}\text { Interstate forgery } \\
\text { Other forgery } \\
\text { Counterfeiting }\end{array}$ & $\begin{array}{l}12 \\
16 \\
13\end{array}$ & $\begin{array}{l}46 \\
29 \\
61\end{array}$ & $\begin{array}{r}43 \\
52 \\
7\end{array}$ & $\begin{array}{l}12 \\
18 \\
32\end{array}$ & $\begin{array}{l}20 \\
21 \\
27\end{array}$ \\
\hline $\begin{array}{l}\text { Weapons and explosives } \\
\text { Extortion, racketeering, } \\
\text { and threats } \\
\text { Simple assault }\end{array}$ & $\begin{array}{r}24 \\
10 \\
0\end{array}$ & $\begin{array}{l}44 \\
72 \\
46\end{array}$ & $\begin{array}{l}41 \\
23 \\
40\end{array}$ & $\begin{array}{r}16 \\
5 \\
15\end{array}$ & $\begin{array}{r}35 \\
29 \\
0\end{array}$ \\
\hline All offenses & 17 & 43 & 36 & 21 & 26 \\
\hline
\end{tabular}

a Offenses are those shown in Table 3 supra, except where category frequencies cannot be computed, owing to missing data. See text at note 172 supra.

b Based on total number of matters received for each offense.

c Percentages are based on number of declined matters in each offense category that had known reasons. "Convictability" includes all combinations of convictability reasons with other factors. "Prosecution Alternatives" includes combinations of prosecution alternatives with policy reasons. Because of rounding, some rows do not total $100 \%$.

d Excludes matters declined for convictability reasons. See text at note 175 infra.

convictability problems. ${ }^{175}$ With two exceptions, all offenses that had a lower-than-average gross prosecution rate have a lower-than-

175 Specifically, we calculated the adjusted prosecution rate for each offense by dividing the number of matters prosecuted by the estimated total number of matters received that had a sufficient basis for prosecution. The latter figure equals the sum of (1) matters prose- 
average adjusted prosecution rate, and vice versa. The adjusted prosecution rates for embezzlement and extortion cases are now somewhat higher than the average, which indicates that there is apparently no particular policy against prosecution of such offenses. The overall adjusted prosecution rate of $26 \%$ is somewhat higher than the gross rate of $17 \%$; nevertheless, prosecution alternatives or policy considerations lead to declination of three out of four "convictable" cases.

In addition to the crime charge, it was demonstrated in the article $^{176}$ that the probability of prosecution is directly related to certain details of the offense involved. We can now reexamine these implicit prosecution criteria to see how they are related to known reasons for declination. ${ }^{177}$ As shown in Table 15, the failure to prosecute marijuana cases involving less than one pound of contraband is not due to either convictability problems or attractive alternatives to prosecution. Such reasons do, however, account for all of the declinations of marijuana cases involving more than one pound of contraband, and most of the declinations of cocaine and heroin offenses. ${ }^{178}$ Cases involving loss of over $\$ 500$ are also more likely to involve convictability problems, and are rarely declined for policy reasons alone. ${ }^{179}$ The number of defendants involved also affects the probability of prosecution. ${ }^{180}$ Matters with more than

cuted, plus (2) matters declined for reasons other than "convictability." Matters with unknown reasons for declination posed a problem, since their inclusion in the denominator would assume, in effect, that they were all prosecutable; to avoid this bias, we estimated the reasons for declination of these matters on the basis of the declinations with known reasons, in each offense category.

${ }^{276}$ See text at notes 35-40 supra.

${ }^{277}$ Some of the prosecution criteria previously discussed, such as the amount of cocaine or heroin and the presence or absence of conspiracy charges, cannot be verified by the means described in the text due to an insufficient number of sample matters with known offense details and reasons for declinations.

${ }^{178}$ When declinations involving convictability reasons are excluded, the previously noted differences in prosecution rates for these three drug types become even greater:

\begin{tabular}{lcc} 
marijuana & $\begin{array}{c}\text { Gross prosecution } \\
\text { rate (from Table 4) }\end{array}$ & $\begin{array}{c}\text { Adjusted prosecution } \\
\text { rate }\end{array}$ \\
\cline { 2 - 3 } cocaine & $5 \%$ & $6 \%$ \\
heroin & $37 \%$ & $42 \%$ \\
nan & $52 \%$ & $71 \%$
\end{tabular}

178 The exclusion of declinations involving convictability reasons lowers the median dollar value of loss in declined matters from $\$ 325$ to $\$ 229$; the median dollar value in prosecuted cases was $\$ 1,700$, see Table 5 supra.

180 See note 40 supra. 
three defendants are much more likely to be declined because of an attractive alternative, and policy reasons alone were never a basis for declination. Thus, these three variables-amount and type of drug, amount of loss, and number of defendants-appear to reflect fairly consistent prosecution policies, and the patterns observed previously are not due to coincidental variations in the strength of the evidence or the availability of prosecution alternatives. Moreover, there is a consistent tendency to cite the "strongest" reasons when justifying declination of the offenses with high prosecution rates. Thus, when a strong positive prosecution criterion (such as loss over $\$ 500$ ) is present, policy reasons alone are generally not deemed sufficient to justify declination.

TABLE 15

Categories of Reasons for Dechination of Matters BY VARIOUS OFFENSE DETAILS

\begin{tabular}{|c|c|c|c|}
\hline Offense Details & $\begin{array}{l}\text { Convictability } \\
\text { (Percentage) }\end{array}$ & $\begin{array}{l}\text { Prosecution } \\
\text { Alternatives } \\
\text { (Percentage) }\end{array}$ & $\begin{array}{c}\text { Policy Reasons } \\
\text { Only } \\
\text { (Percentage) }\end{array}$ \\
\hline $\begin{array}{l}\text { Marijuana } \\
1 \mathrm{lb} \text {. or less } \\
\text { over } 1 \mathrm{lb} \text {. }\end{array}$ & $\begin{array}{r}8 \\
25\end{array}$ & $\begin{array}{r}8 \\
75\end{array}$ & $\begin{array}{r}83 \\
0\end{array}$ \\
\hline $\begin{array}{l}\text { Marijuana } \\
\text { all amounts (or } \\
\text { unknown amount) }\end{array}$ & 14 & 19 & 67 \\
\hline $\begin{array}{l}\text { Cocaine } \\
\text { all amounts }\end{array}$ & 20 & 50 & 30 \\
\hline $\begin{array}{l}\text { Heroin } \\
\text { all amounts }\end{array}$ & 56 & 33 & 11 \\
\hline $\begin{array}{l}\text { Loss } \\
\text { less than } \$ 500 \\
\$ 500 \text { or more }\end{array}$ & $\begin{array}{l}36 \\
66\end{array}$ & $\begin{array}{l}42 \\
32\end{array}$ & $\begin{array}{r}22 \\
2\end{array}$ \\
\hline $\begin{array}{l}\text { Number of defendant } \\
\text { 1-3 } \\
4-7\end{array}$ & $\begin{array}{l}43 \\
36\end{array}$ & $\begin{array}{l}36 \\
64\end{array}$ & $\begin{array}{r}21 \\
0\end{array}$ \\
\hline All matters & 43 & 36 & 21 \\
\hline
\end{tabular}

NoTE: Percentages are básed on number of declined matters in each offense subcategory with known reasons for declination. "Convictability" includes all combinations of convictability reasons with other factors. "Prosecution Alternatives" includes combinations of prosecution alternatives with policy reasons. Because of rounding, not all rows total $100 \%$. 
TABLE 16

Categories of Reasons for Declination by Prior Record of Defendant

\begin{tabular}{lccc}
\hline \hline \multicolumn{1}{c}{ Prior Record } & $\begin{array}{c}\text { Convictability } \\
\text { (Percentage) }\end{array}$ & $\begin{array}{c}\text { Prosecution } \\
\text { Alternatives } \\
\text { (Percentage) }\end{array}$ & $\begin{array}{c}\text { Policy Reasons } \\
\text { Only } \\
\text { (Percentage) }\end{array}$ \\
\hline No convictions & 33 & 38 & 29 \\
$\begin{array}{l}\text { State and/or federal } \\
\text { convictions }\end{array}$ & 30 & 49 & 21 \\
$\begin{array}{l}\text { Unknown } \\
\text { No known convictions }\end{array}$ & 53 & 33 & 14 \\
\cline { 2 - 4 } All defendants & 47 & 35 & 18 \\
\hline
\end{tabular}

NotE: See Table 15 Note supra.

"Combines "no convictions" and "unknown."

As noted in the article, ${ }^{181}$ our data on declined prosecutions frequently included the subject's prior record of arrests and convictions. We do not have similar data on prosecuted defendants, but an examination of the reasons for declination of suspects with known prior records may suggest whether or not this factor is a strong positive prosecution criterion. If it is, then the patterns discussed above would lead us to expect that the prosecution of defendants with a known record would tend to be declined for reasons related to convictability. As shown in Table 16, however, the defendants with a known conviction record are actually less likely to be declined for these reasons than either defendants with no such record, or defendants with an unknown record, ${ }^{182}$ and $21 \%$ of the previously convicted defendants were declined for policy reasons alone. Thus, if a known prior record weighs in favor of federal prosecution, this factor apparently can be overridden by policy

181 See note 31 supra.

102 For $62 \%$ of suspects whose prosecutions were declined for known reasons, there were no indications of a prior record or absence of a prior record. It is possible that this large unknown group includes suspects with known prior convictions, but it seems unlikely that a fact as important as the defendant's prior conviction would have been known to the Assistant U.S. Attorney and not noted somewhere in the file or court records. Thus, the "unknown prior record" suspects probably had no known convictions. The much higher incidence of convictability problems among these suspects may explain why the Assistant U.S. Attorneys did not feel it necessary to investigate the suspect's prior record, or to mention the absence of a prior record, if this was known. 
considerations. In other words, prior record apparently is not a strong positive factor weighing in favor of prosecution. ${ }^{188}$

18s Prior record may, however, be a factor favoring prosecution to a moderate degree. See Admin. Office of the U.S. Courts, Federal Ofpenders in United States District CourTs-1974, at 27 (1977). This data only covers convicted defendants (who may or may not be representative of all prosecuted defendants in this regard). About $63 \%$ of such convicted defendants had known criminal history information. 


\section{Appendix C: Analysis of Declinations by Screening Stages}

The analysis in the article examined reasons for declination and characteristics of declined matters as a whole, in order to determine the principles used by the U.S. Attorney in screening cases for prosecution. ${ }^{184}$ Even if these principles are appropriate and consistently applied, however, it is also important that they be applied efficiently. The U.S. Attorney's office for the Northern District uses a multi-stage screening process, and an examination of the case characteristics and reasons for declination at each of these stages will show more precisely how this office goes about the task of weeding out cases.

In particular, we will examine two aspects of the pretrial screening process in the Northern District. First, there is the initial screening decision, made by the Chief of the Criminal Division on the same day the matter is received, as to whether to enter an "immediate declination."188 If the screening process is operating efficiently, then such immediate declinations should include those matters as to which fairly clear-cut policies against prosecution have been developed. Declinations entered after more extensive examination, on the other hand, should represent either cases of "borderline" prosecution merit, cases for which declination reasons subsequently develop, or cases presenting other "unforeseeable" factors that prevented immediate disposal of the case.

A second level of decision making involves the question whether or not to take the defendant into custody pending the decision about prosecution. Unlike state prosecutors, who normally do not learn about a criminal investigation until after the police have made one or more arrests, federal prosecutors usually have some control over whether, and when, an arrest takes place. It is thus possible to minimize, if not eliminate, "unnecessary" arrests-that is, arrests that do not lead to eventual prosecution. The prosecutor's screening criteria can be applied to the arrest decision, thus preventing the arrest of clearly "unprosecutable" defendants. ${ }^{186} \mathrm{We}$ will therefore examine the frequency and characteristics of all sample declinations following actual or attempted ar-

${ }^{184}$ See Parts III-V supra.

198 See text at note 28 supra.

186 Occasionally, however, arrest may be justified even when prosecution is unlikely-for example, to terminate a fist fight or other violent behavior. See text at note 209 infra. See also note 37 supra. 
rest-referred to here as "magistrate declinations"187-to see whether the arrest was justified at the time by apparent prosecution merit or other factors. In an "efficient" system, we would expect to find that the proportion of declinations made after arrest is relatively low, and that there is some good reason why these unprosecuted defendants were arrested.

The following analysis of the initial screening and arrest decisions will contrast "immediate" with "magistrate" declinations. Both will also be compared to a third group of declinations, those involving cases that survive the initial screening but that are subsequently declined without any attempt to obtain the arrest of any defendant. This large group will be referred to as "intermediate declinations."

\section{A. The Initial Screening Stage: Immediate Declinations}

As noted in the article, ${ }^{188}$ slightly more than half of all cases referred to the Criminal Division become "immediate declinations," while the remainder of the cases receive more extensive evaluation by the office. The only definite office "rule," at this stage, is that a matter will not be declined immediately if any defendant has already been arrested by federal agents. ${ }^{180}$ The data, however, suggest that many immediate declinations are, in practice, "routine." For one thing, the sheer volume of immediate declinations-constituting $70 \%$ of all declinations-suggests the application of well-established prosecution policies. ${ }^{100}$ Of course, it might also reflect overly hasty "disposal" of cases, so further analysis of the immediate declinations is needed to see if these matters display characteristics that make speedy disposition desirable.

Table 17 shows the stages of screening at which various offenses are declined. There is a strong tendency for offenses with the lowest prosecution rates to be declined immediately-for example, theft of government property, auto theft with no conspiracy, marijuana offenses, and civil rights cases. Conversely, several

187 Although our primary concern is with actual arrests that did not lead to prosecution, we will examine all magistrate filings, since these represent "attempted" arrests prior to formal charging, and the fact of actual arrest subsequent to the filing is largely a matter of luck in finding the defendant. Six of the 70 sample defendants whose cases were declined after the filing of a complaint with the U.S. magistrate were never arrested or otherwise apprehended.

${ }^{18 s}$ See text at note 28 supra.

180 Many such matters, however, are subsequently declined. See text at note 196 infra.

100 The large number of these declinations may also suggest that pre-referral screening by federal law enforcement agencies is limited. See note 11 supra. 
offenses with very high prosecution rates are rarely declined at this early stage: mail theft, heroin offenses, and tax fraud. Drug offenses display a clear inverse correlation between prosecution rates and proportion of immediate declinations. Thus, it appears that the first stage of screening operates efficiently to separate out offenses that are rarely prosecuted from those with a higher probability of prosecution.

TABLE 17

Cases Declined at gach Stage: Offense

\begin{tabular}{|c|c|c|c|c|}
\hline \multirow[b]{2}{*}{ Offense Category } & \multicolumn{3}{|c|}{$\begin{array}{c}\text { Stage of DeClination } \\
(\text { PERCENTAGE })^{a}\end{array}$} & \multirow{2}{*}{$\begin{array}{l}\text { Gross Prosecu- } \\
\text { TION RATE } \\
\text { (PERCENTAGE) b }\end{array}$} \\
\hline & Immediate & Intermediate & Magistrate & \\
\hline Violent offenses & 71 & 0 & 29 & 50 \\
\hline $\begin{array}{l}\text { Mail theft } \\
\text { Theft of U.S. property } \\
\text { Theft from interstate } \\
\text { shipment } \\
\text { Stolen autos (no } \\
\text { conspiracy) }\end{array}$ & $\begin{array}{l}19 \\
88 \\
70 \\
93\end{array}$ & $\begin{array}{r}39 \\
12 \\
\\
26 \\
7\end{array}$ & $\begin{array}{r}42 \\
0 \\
4 \\
0\end{array}$ & $\begin{array}{r}51 \\
4 \\
8 \\
5\end{array}$ \\
\hline $\begin{array}{l}\text { Marijuana } \\
\text { Cocaine* } \\
\text { Heroin * }\end{array}$ & $\begin{array}{l}98 \\
57 \\
18\end{array}$ & $\begin{array}{r}2 \\
17 \\
10\end{array}$ & $\begin{array}{r}0 \\
26 \\
72\end{array}$ & $\begin{array}{r}5 \\
37 \\
52\end{array}$ \\
\hline $\begin{array}{l}\text { Mail fraud } \\
\text { Tax fraud* } \\
\text { False statements } \\
\text { Other fraud } \\
\text { Embezzlement }\end{array}$ & $\begin{array}{r}62 \\
0 \\
60 \\
57 \\
65\end{array}$ & $\begin{array}{r}38 \\
100 \\
40 \\
42 \\
35\end{array}$ & $\begin{array}{l}0 \\
0 \\
0 \\
1 \\
0\end{array}$ & $\begin{array}{r}21 \\
59 \\
21 \\
7 \\
11\end{array}$ \\
\hline $\begin{array}{l}\text { Interstate forgery } \\
\text { Other forgery } \\
\text { Counterfeiting }\end{array}$ & $\begin{array}{l}67 \\
76 \\
48\end{array}$ & $\begin{array}{l}20 \\
13 \\
28\end{array}$ & $\begin{array}{l}13 \\
11 \\
24\end{array}$ & $\begin{array}{l}12 \\
16 \\
13\end{array}$ \\
\hline $\begin{array}{l}\text { Weapons and explosives } \\
\text { Extortion, racketeering, } \\
\text { and threats } \\
\text { Civil rights } \\
\text { Simple assault }\end{array}$ & $\begin{array}{l}53 \\
69 \\
98 \\
60\end{array}$ & $\begin{array}{r}41 \\
31 \\
2 \\
20\end{array}$ & $\begin{array}{r}6 \\
0 \\
0 \\
20\end{array}$ & $\begin{array}{r}24 \\
10 \\
0 \\
0\end{array}$ \\
\hline All offenses & 70 & 23 & 7 & 17 \\
\hline
\end{tabular}

*Fewer than 10 cases

${ }^{a}$ Based on total number of declined matters in each offense category.

b Based on total matters received in each offense category. See Tables 2 \& 3 supra. 
Table 18 compares the dollar amounts of loss, by offense, among the three stages of declination, and Table 19 summarizes other differences between these groups. Given the overall prosecution policies discussed in the body of this article, we would expect that an efficient initial screening process would tend to weed out the most trivial cases, in terms of dollar amounts of loss, and that immediate, in contrast to later, declinations would probably contain matters with fewer defendants per case, more unknown parties, and fewer defendants with serious criminal records. To some extent, the case attributes shown in Tables 18 and 19 conform to this graduated model, although there are several exceptions. Embezzlement, ${ }^{191}$ other forgery, and counterfeiting cases do not show lower dollar amounts in the initial declination stage, and the first two declination groups do not differ in number of defendants per case.

TABLE 18

Cases Declined at Each Stage: Amount of Loss

\begin{tabular}{|c|c|c|c|c|c|c|}
\hline \multirow[b]{3}{*}{ OFFENSE } & \multicolumn{6}{|c|}{ Stage of Declination } \\
\hline & \multicolumn{2}{|c|}{ Immediate } & \multicolumn{2}{|c|}{ Intermediate } & \multicolumn{2}{|c|}{ Magistrate } \\
\hline & $\begin{array}{c}\text { Median } \\
\text { Amount }(\$)\end{array}$ & $\begin{array}{l}\text { Sample } \\
\text { Size }\end{array}$ & $\begin{array}{c}\text { Median } \\
\text { Amount (\$) }\end{array}$ & $\begin{array}{l}\text { Sample } \\
\text { Size }\end{array}$ & $\begin{array}{c}\text { Median } \\
\text { Amount (\$) }\end{array}$ & $\begin{array}{l}\text { Sample } \\
\text { Size }\end{array}$ \\
\hline Mail theft & $*$ & $*$ & 186 & 4 & 200 & 7 \\
\hline $\begin{array}{l}\text { Theft from inter- } \\
\text { state shipment }\end{array}$ & 200 & 16 & 2,125 & 10 & $*$ & * \\
\hline Fraud & 180 & 9 & 12,165 & 18 & $*$ & $*$ \\
\hline Embezzlement & 1,090 & 10 & 850 & 6 & $*$ & $*$ \\
\hline $\begin{array}{l}\text { Interstate for- } \\
\text { gery }\end{array}$ & 575 & 9 & 985 & 6 & 1,180 & 3 \\
\hline Other forgery & 289 & 14 & 315 & $\mathbf{5}$ & 240 & 4 \\
\hline Counterfeiting & 50 & 3 & $*$ & * & 40 & 5 \\
\hline All offenses & 266 & 83 & 1,600 & 61 & 215 & 21 \\
\hline
\end{tabular}

* Fewer than 3 cases with known dollar amounts

191 The higher amounts involved in the embezzlement cases that were declined immediately appear to be associated with a very high incidence of convictability problems. This is not true, however, of the counterfeiting and "other forgery" cases. 
TABLE 19

Cases Declined at Each Stage: Other Details

\begin{tabular}{|c|c|c|c|}
\hline DETAIL OF OFFENSE & Immediate & $\begin{array}{l}\text { Stage of DecLination } \\
\text { Intermediate }\end{array}$ & Magistrate \\
\hline $\begin{array}{l}\text { Average number of defendants } \\
\text { per case }\end{array}$ & $1.34(288)$ & $1.29(157)$ & $1.57(46)$ \\
\hline Proportion of unknown subjects & $18 \%(385)$ & $7 \%(224)$ & $0 \%(70)$ \\
\hline $\begin{array}{l}\text { Proportion of defendants with } \\
\text { prior convictions (of total } \\
\text { with known criminal history) a }\end{array}$ & $18 \%(113)$ & $48 \% \quad(63)$ & $49 \%(49)$ \\
\hline $\begin{array}{l}\text { Proportion of defendants with } \\
\text { prior convictions (all } \\
\text { defendants) b }\end{array}$ & $5 \%(385)$ & $13 \%(224)$ & $34 \%(70)$ \\
\hline
\end{tabular}

Note: Figures in parentheses are the number of cases or defendants upon which each percentage or average is based.

a The exclusion of defendants whose prior conviction record was not mentioned in the case file results, in effect, in the assumption that these defendants had conviction records that were similar to the defendants whose records were mentioned.

b The inclusion of all sample defendants in the calculation of the percentage assumes that the defendants whose prior record was not mentioned had no prior convictions, or at least none that was known to the prosecutors handling the case.

We turn, then, to the reasons for declination asserted at each stage of screening, to see what they can tell us about the nature and validity of the initial screening decision. As shown in Table 20, triviality of the offense is a factor in about half of the immediate declinations, whereas this reason figures in only 25 to $30 \%$ of subsequently declined defendants. State prosecution is also more frequently cited at the first screening stage, whereas subsequent declinations are more likely to involve a legal bar or other alternatives.

Most of the differences in Table 20 are consistent with the use of a procedure that eliminates obviously unprosecutable cases on first inspection, and subjects other cases to further examination. Thus, if a case involves an amount of loss or contraband that is lower than the amount generally required for prosecution, this can be-and apparently is-readily determined at the outset. Similarly, if full investigation has uncovered no known suspect and the offense does not have a high prosecution priority, there may be no need for extended evaluation of the matter.

On the other hand, some of the more subtle defects that lead to the use of the insufficient-evidence reason are less likely to be 
TABLE 20

Cases Declined at Each Stage: Reason Groups

\begin{tabular}{|c|c|c|c|c|}
\hline \multirow[b]{2}{*}{ CATEGORY } & \multirow[b]{2}{*}{ REAson Group } & \multicolumn{3}{|c|}{$\begin{array}{c}\text { Stage of Declination } \\
\text { (Percentage) }\end{array}$} \\
\hline & & Immediate & Intermediate & Magistrate \\
\hline \multirow[t]{4}{*}{ Convictability } & No crime & 14 & 11 & 0 \\
\hline & Insufficient evidence & 20 & 30 & 20 \\
\hline & Parties unavailable & 15 & 8 & 13 \\
\hline & Legal bar & 1 & 6 & 25 \\
\hline \multirow[t]{3}{*}{$\begin{array}{l}\text { Prosecution } \\
\text { Alternatives }\end{array}$} & State prosecution & 31 & 14 & 18 \\
\hline & $\begin{array}{l}\text { Civil/administrative } \\
\text { remedies }\end{array}$ & 7 & 14 & 7 \\
\hline & Other & 7 & 25 & 15 \\
\hline \multirow[t]{3}{*}{ Policy Reasons } & Minor offense & 51 & 25 & 29 \\
\hline & Defendant characteristics & 22 & 16 & 22 \\
\hline & Other & 2 & 7 & 4 \\
\hline \multicolumn{2}{|c|}{ Average number of reasons per defendant } & 1.7 & 1.6 & 1.5 \\
\hline \multicolumn{2}{|c|}{ Number of defendants } & 317 & 174 & 55 \\
\hline
\end{tabular}

apparent upon initial inspection, and this is also reflected in Table 20. Similarly, alternatives to prosecution, such as deferred prosecution, restitution, and parole revocation, are more likely to become available after further investigation. Magistrate declinations are especially likely to involve search problems and unconstitutional delays in prosecution-that is, legal bars. Although some search problems caused by state and local arrests are reflected in intermediate declinations, most relevant searches are incident to federal arrest. The reason for the greater incidence of delay problems among magistrate declinations is that constitutional speedy-trial issues arise only after the defendant has been arrested. ${ }^{192}$

Certain reasons for declination appear equally likely to be cited at earlier and later screening stages. In the case of defendant 
characteristics, such factors as the age or prior record of the defendant are evident at the outset or after minimal police investigation. ${ }^{193}$ But other mitigating circumstances, such as the defendant's services as a witness or informer, are more likely to become relevant at a later stage. Similarly, some kinds of civil or administrative remedies are already being pursued at the time of referral to the U.S. Attorney, while others develop or are chosen later.

Substantial reliance on state prosecution in immediate declinations raises a question: how can the U.S. Attorney know, at the time of initial screening, that state prosecution will be undertaken? It was noted earlier ${ }^{194}$ that about $50 \%$ of all federal cases in which prosecution is declined because of probable state action do not involve completed or even pending state prosecution; when immediate declinations are analyzed separately, a similar pattern emerges. Thus, the timing of declinations based on state prosecution suggests that many such cases involve pure policy considerations rather than the choice of an effective alternative-that is, such cases ought to be prosecuted by state rather than federal authorities.

Table 21 shows the combinations of convictability, prosecution-alternative, and policy reasons at each stage of declination, and Table 22 shows the overall frequencies for these three categories. Policy reasons, whether alone or in combination, are most common among immediate declinations; the relative sufficiency of policy reasons among immediate declinations (21\% were "policy only") further suggests that these dispositions are based on wellestablished prosecution criteria that are considered to be strong reasons for declination.

To summarize, the volume, characteristics, and reasoning of immediate declinations suggest that they are based on prosecution policies that are capable of application without further investigation or extended examination of specific offense and offender characteristics. Immediate declinations rest on the most basic prosecution policies, ones that are observed in the analysis of declinations

${ }^{193}$ Nineteen percent of immediate declinations were based on the suspect's lack of a prior record, whereas only $8 \%$ of the intermediate and magistrate declinations were based on this factor. The age of the suspect is about equally likely to be cited in each group (6\% of immediate declinations versus $4 \%$ of subsequent declinations). The use of the age reason in intermediate declinations suggests that this factor is only relevant in close cases that would be prosecuted but for other problems. Age was never the sole basis for declination at any stage.

184 See Table 13 supra. 
TABLE 21

Cases Dechined at Each Stage:

Categories of Reasons alone and in Combination

\begin{tabular}{|c|c|c|c|}
\hline & \multicolumn{3}{|c|}{$\begin{array}{c}\text { STAGE OF Declination } \\
\text { (PERCENTAGE) }\end{array}$} \\
\hline & Immediate & Intermediate & Magistrate \\
\hline Convictability OnIy & 18 & 25 & 20 \\
\hline Prosecution Alternative Only & 20 & 23 & 24 \\
\hline Policy Reason Only & 21 & 12 & 15 \\
\hline $\begin{array}{l}\text { Convictability + Prosecu- } \\
\text { tion Alternative }\end{array}$ & 3 & 12 & 0 \\
\hline Convictability + Policy Reason & 19 & 13 & 25 \\
\hline $\begin{array}{l}\text { Prosecution Alternative + } \\
\text { Policy Reason }\end{array}$ & 16 & 13 & 16 \\
\hline All Three & 3 & 2 & 0 \\
\hline Total & 100 & 100 & 100 \\
\hline
\end{tabular}

TABLE 22

Cases Declined at Each Stage: Category of Reasons

\begin{tabular}{|c|c|c|c|}
\hline & \multicolumn{3}{|c|}{$\begin{array}{c}\text { STAGe of Declination } \\
\text { (PERCENTAGE) }\end{array}$} \\
\hline & Immediate & Intermediate & Magistrate \\
\hline Convictability Reasons & 43 & 52 & 45 \\
\hline Prosecution Alternatives & 42 & 50 & 40 \\
\hline Policy Reasons & 59 & 40 & 56 \\
\hline $\begin{array}{l}\text { Number of reasons per } \\
\text { defendant }\end{array}$ & 1.44 & 1.42 & - 1.41 \\
\hline
\end{tabular}

as a whole; these policies-particularly the de minimis rationale-appear to be so "axiomatic" that they permit immediate declination. This finding has broader policy implications: if fairly routine, easily applied "rules" already exist, then it may be quite feasible to reduce them to written form. ${ }^{195}$ At the same time, the 
fact that immediate declinations tend to dispose of the clearest cases suggests that the screening process is operating efficiently, weeding out suspects as soon as it is apparent that the cases against them lack merit.

\section{B. The Decision to Arrest Pending Final Screening: "Magistrate" Declinations}

The vast majority of declinations by federal prosecutors occur before the arrest of any of the suspects, as was previously noted. ${ }^{196}$ Even among defendants who are actually prosecuted, the arrest is most often delayed until after the filing of formal charges. ${ }^{197}$ This sparing use of the arrest power probably reflects the nature of federal crime and offenders. Many offenders are middle-class persons with substantial roots in their communities, who are unlikely to flee before they can be apprehended. ${ }^{198}$ Moreover, even if a defendant does try to flee, he or she would probably have to leave the country to escape the nationwide powers of federal police agencies to arrest and extradite. ${ }^{199}$

Occasionally, however, federal authorities may need to obtain the immediate arrest of the defendant prior to the filing of formal charges. In such cases, a complaint is filed with a U.S. magistrate, either before or immediately after arrest, ${ }^{200}$ and if the subsequent preliminary hearing results in a finding of probable cause, the defendant is "held to district court."201 But not all such defendants

${ }^{196}$ See text at note 23 supra.

197 At the time of our study, the prosecution of felonies and serious misdemeanors required the filing of an indictment or information in U.S. district court. See FED. R. CRIM. P. 7; 18 U.S.C. $\$ 3401$ (1976). An arrest warrant may be based on an indictment or information or on a complaint filed with a U.S. magistrate. FED. R. CRIM. P. 4 \& 9. During the two-andone-half-year period ending December 31,1978 , only $37 \%$ of defendants prosecuted in all 94 U.S. district courts were arrested prior to formal charging, and the percentage in the Northern District was $40 \%$. See Admin. Ofrice of the U.S. Courts, Fourth Report on the ImPlementatpon of Trtue I of the Speedy Trial Act of 1974, supra note 24, Appendices A \& C. In our sample, which covers a slightly earlier period, $45 \%$ of prosecuted defendants were arrested prior to formal charging ( $42 \%$, excluding transfers into the district).

${ }^{198}$ Under the liberal terms of the federal bail statute, 18 U.S.C. $\S 3146$ (1976), most defendants are released pending trial. Fifty-six percent of the prosecuted defendants in our sample were released on their own recognizance, and $94 \%$ obtained release on recognizance or money bail. Thus arrest itself would rarely serve to assure either appearance at trial or cessation of criminal activities.

${ }^{190}$ Defendants arrested outside of the federal district in which they are charged are ordered "removed" to the charging district upon a finding of probable cause, FED. R. CRIM. P. 40, and are transported by U.S. marshals at no direct expense to the charging authorities.

${ }^{200}$ See Fed. R. CRIM. P. 4 \& 5.

${ }^{201}$ See id. 5.1(a). This "preliminary examination" is an adversary proceeding, but it is 
are eventually prosecuted, and the existence of these seemingly "unnecessary" arrests suggests inefficiency as well as unfairness to those arrested. The purpose of the following discussion is to try to determine why the magistrate declinations in our sample required arrest but not prosecution, and whether the number of such declinations could be reduced by more active participation by the prosecutor in the arrest decision.

At the time of our study, the U.S. Attorney for the Northern District had a policy that magistrate's complaints and arrest warrants could not be issued without the approval of an Assistant U.S. Attorney. ${ }^{202}$ This procedure does not give the prosecutor control over all arrests, since many are made by officers acting without a warrant, ${ }^{203}$ but in these latter cases, the prosecutor can refuse to approve the filing of a complaint after arrest if prosecution does not appear warranted. Such a system makes it possible, in theory at least, to avoid filing any complaints in unprosecutable matters. Moreover, complaints that are filed should then need to be declined only if unforeseeable evidentiary problems or alternatives to prosecution later develop.

As Table 17 illustrates, magistrate declinations have not been completely eliminated in the Northern District, but the incidence of such declinations is low- $7 \%$ of all declined matters. In addition, the variation in the frequency of magistrate filings by offense suggests that such filings are generally based on valid law enforcement needs for an early arrest. For example, many violent and simple assault offenses require an "on the spot" arrest to terminate or prevent continuing criminal behavior; cocaine and heroin offenses often require arrest immediately after the sale to an agent or informant in order to prevent the flight of the accused or to recover the "advance funds" used to make the purchase. ${ }^{204}$ Yet not

frequently waived; waiver occurred for over half of the defendants in our sample who were arrested prior to formal charging.

${ }^{202}$ This procedure was strongly recommended by the most recent national crime commission. See U.S. National Advisory Comm'n on Criminal Justice Standards and Goals, supra note 2, Standard 1.2.

${ }^{203}$ Rule 5 of the Federal Rules of Criminal Procedure authorizes such arrests, and the Supreme Court recently held that the fourth amendment does not require police to obtain an arrest warrant in advance, even if they have plenty of time to do so. United States v. Watson, 423 U.S. 411 (1976). Cf. Payton v. New York, 100 S. Ct. 1371, 1382 (1980) (warrantless entry of defendant's home, to effect arrest, requires "exigent circumstances").

204 The immediate arrest of drug offenders might also be used to justify a search "incident" to arrest for further contraband or evidence of drug trafficking, under the rationale of Chimel v. California, 395 U.S. 752, 762-63 (1969). To a lesser extent, this may explain the 
all magistrate filings subsequently declined are so easily explained. For instance, forgery and counterfeiting arrests are frequently made by local police, but federal complaints are often issued as well. Mail theft arrests are equally hard to explain, given the nonviolent nature of these suspects.

At the other extreme, certain white-collar offenses, such as fraud, embezzlement, and "extortion," rarely involve a magistrate filing. ${ }^{205}$ This is probably because such offenders, if prosecuted, do not need to be apprehended until after the filing of formal charges; they are unlikely to flee and do not need to be restrained from continuing their criminal activities. ${ }^{208}$

A comparison of the prosecuted cases in our sample shows that these patterns are not unique to declined matters: although $51 \%$ of all prosecuted cases had a magistrate filing, only $11 \%$ of the fraud and embezzlement cases had such a filing, and none of the extortion cases did. In contrast, $86 \%$ of prosecuted drug cases involved a magistrate filing, and the figures for mail theft and counterfeiting were $89 \%$ and $100 \%$ respectively. Thus, it appears that the decision to file a magistrate complaint is an offense-based decision reflecting the underlying need for prompt arrest of certain types of suspects prior to formal charging. Yet the prosecution of some of these defendants is later declined, and the question remains whether they should have been arrested in the first place. In particular, were they considered prosecutable at the time of arrest?

Table 18, showing average dollar amounts for the three groups of declinations, casts some doubt on the extent to which all arrest decisions are controlled, or at least guided, by prosecution policies. Counterfeiting and other forgery cases declined after a magistrate filing actually involve lower dollar amounts than the immediate declinations, suggesting that the former, too, should be deemed de minimis. The reasons for declination given in magistrate declinations, illustrated in Table 20, further suggest that many of these decisions should have been foreseeable at the time of arrest: $29 \%$ of these reasons involve the triviality of the offense, and $22 \%$ are based on characteristics of the defendant. Overall, $56 \%$ of magistrate declinations are based in whole or in part on "policy" rea-

large number of pre-indictment arrests in forgery, counterfeiting, and mail-theft cases.

${ }^{205}$ Most of the extortion cases in our sample were nonviolent, involving the abuse of official powers rather than physical threats. See Ruff, supra note 13, at 1175-76 (discussing the broad interpretation given to the language of the Hobbs Act, 18 U.S.C. § 1951 (1976)).

${ }^{208}$ Such offenders are rarely "caught in the act," and are almost always released immediately on bail or recognizance. See note 198 supra. 
sons, most of which are determinable at the time of arrest.

To investigate further the possibility that the arrests that were followed by magistrate declinations were not justified by either prosecution merit or other factors, each of the declinations was examined individually. We considered an arrest to be sufficiently explained if (1) the amount of loss or contraband involved made the case potentially prosecutable; ${ }^{207}$ (2) the amount was unknown, but at least one codefendant in the matter was eventually prosecuted; ${ }^{208}$ or (3) the arrest was necessary to terminate violent behavior. ${ }^{209}$ It was not always possible to apply these criteria, since the details of the offense and the circumstances of arrest were sometimes not recorded in either the files of the court or those of the U.S. Attorney. Even where such details were recorded, the above criteria provide an imperfect measure of the extent of "unnecessary" federal arrests. A definitive study would have to be based on the records of the law enforcement agencies involved, and should probably be conducted concurrently with the events in question. The results of this preliminary study, however, may determine whether there is a need for further research or other efforts to improve the efficiency and fairness of arrest decisions.

As shown in Table 23, almost three-fourths of the magistrate declinations met the above conditions for an explained arrest. The "violent" cases included a threat on the life of the President by an individual who turned out to be harmless, a major fight in a Veterans' Hospital (which was settled later by informal mediation), and a spree of window smashing at a federal building by a person who was subsequently found incompetent to stand trial. The arrests

${ }^{207}$ Specifically, crimes were considered sufficiently "prosecutable" if the amounts of loss or contraband involved fell within the range usually found in prosecuted cases for that particular offense, or if the amount of loss or contraband was greater than the median amount involved in all declined cases of that offense. This approach reflects our theory that magistrate declinations should involve the most serious declined cases; it is, however, reasonable to expect such offenses to be at, or slightly below, the threshold for prosecution, as measured by cases actually filed. Thus, it was necessary to set a threshold of "justification" somewhat lower than the least serious prosecuted case.

${ }^{208}$ If a matter is considered prosecutable, it seems appropriate to arrest all known suspects since the relative degrees of responsibility cannot always be determined at the outset, and the less culpable defendants may agree to testify against the others.

${ }^{209}$ It might be argued that arrest is justified whenever it will terminate any illegal behavior (for example, selling drugs), or when the defendant is likely to flee the jurisdiction. In the former case, however, confiscation of the contraband, rather than arrest, is the most effective means of dealing with continuing criminal acts. As for risk of flight, this problem is irrelevant in a clearly nonprosecutable case. Moreover, almost all magistrate declinations receive recognizance bonds, which suggests that failure to appear is not a major concern. See note 211 infra. 
that involved potentially prosecutable amounts of loss or contraband were later declined for a variety of reasons, including actual state prosecution or conviction, deferred prosecution, a plea agreement, and other unforeseeable convictability problems, such as the death of the suspect.

TABLE 23

APPARENT EXPLaNation For ARrest OF DECLINED DEFENDANTS

Percentage of Defendants*

Explained Arrests

Necessary to terminate violent behavior 15

Prosecutable amount of loss or contraband

Unknown amount; codefendant prosecuted

4

Subtotal

74

Unexplained Arrests

Drug offenses; unprosecutable amount

Forgery; unprosecutable amount

Counterfeiting; unprosecutable amount

Other unprosecutable offenses

15
55
4

Subtotal

26

Total

100

*Sample size: 53 defendants

Note: For a discussion of the criteria used to assess arrest justification, see text at notes 207-209 supra.

The unexplained magistrate declinations most often involved drug, forgery, and counterfeiting offenses-for example, 0.1 ounce of cocaine or a twenty-dollar counterfeiting case. The need for immediate arrest in these types of cases has already been discussed, ${ }^{210}$ but the question remains why federal authorities were interested in these minor offenders in the first place. Given the continuous "feedback" from the U.S. Attorney's office to the investigating agencies concerning the outcome of previously referred matters, it seems unlikely that the agencies are ignorant of current prosecution criteria. A more likely hypothesis is that these "small 
fish" were thought, at the time of arrest, to be involved in criminal activities of a larger scale, or were at least expected to provide information leading to the apprehension of major sellers and distributors of drugs, counterfeit money, or forged securities. ${ }^{211}$ Such an approach may represent the only effective means of investigating such crimes, which often lack any direct, complaining witness, but it obviously imposes certain costs on the court system and the defendants involved. More detailed studies of these arrests should focus on the law enforcement needs they serve, and the availability of alternate strategies.

Future research should also consider the role of the U.S. Attorney, to discover if more active advance screening or better communication of current prosecution policy might further reduce the number of arrests or magistrate filings not leading to prosecution. The extent to which the U.S. Attorney currently controls arrest and magistrate filings is unclear. At least $50 \%$ of all pre-indictment arrests appear to have been made prior to the filing of a complaint (that is, without a warrant), ${ }^{212}$ and although informal telephone conversations sometimes precede arrest, it seems unlikely that the U.S. Attorney is able to do more than decide that such matters are immediate declinations. Moreover, defendants charged with drug offenses, mail theft, counterfeiting, and forgery frequently are caught in the act, which leads to immediate arrest and referral for prosecution, with little opportunity for advance approval. Still, the U.S. Attorney could refuse to approve the filing of a complaint in these matters, thus releasing the defendant and conserving resources. ${ }^{213}$ Yet this was never done in the cases in our sample.

The routine approval of complaints in apparently unprosecutable matters may be done to protect the officers from charges of false arrest or to preserve the admissibility of any evidence seized, "just in case." Indeed, such routine filing may be desirable from a broader policy perspective. If the prosecutor refuses to file a complaint, the officers will never receive a judicial critique

21 Another reason for arresting relatively minor offenders might be to achieve informal retributive or deterrent effects by giving these defendants a "taste of jail." This explanation, however, seems less likely, given the very low pretrial detention rates for most arrests in our sample: $87 \%$ of the defendants in magistrate declinations were released on their own recognizance, and only $3 \%$ were detained at any time prior to declination.

${ }^{212}$ Fifty-one percent were arrested at least one day before issuance of the warrant, but many more were arrested on the same day, and the exact order of events was not indicated in the records.

${ }^{213}$ See text and note at note 202 supra. 
of their arrest decision, and any later false-arrest claim or motion to suppress will lack the prompt, written record that the warrant procedure provides. Once the complaint is filed, however, prosecutors should move expeditiously to dismiss the case, if it lacks prosecutable merit. ${ }^{214}$

214 In our sample of magistrate declinations, the average length of time between the filing of the complaint and the entry of the declination was 261 days, and only a small portion of this delay appeared to reflect paperwork delays or prosecution of codefendants. 